الجينات التنظيمية وعلاقتها بالقدرات الابتكارية لدى العاملين

$$
\text { بالمؤسسات الرياضية }
$$

د/ إيهاب محمد خيرى (*) - (")

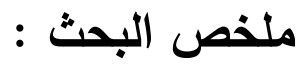

يهلف البحث الى التعرف على العلاقة بين الجينات التنظيمية والقدرات الابتكارية لاى

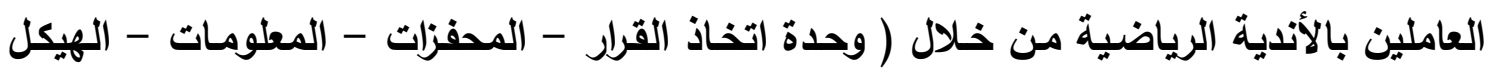

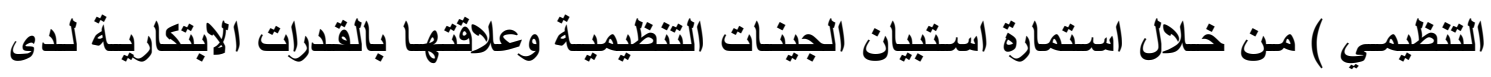

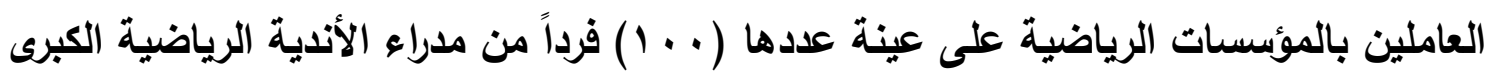

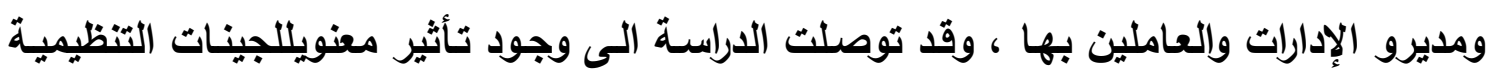

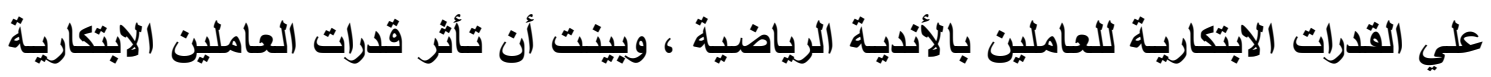

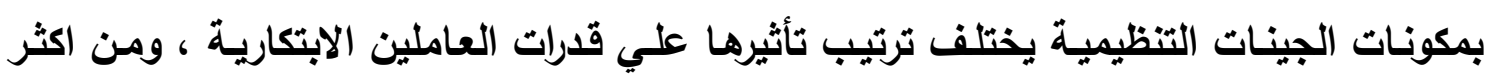

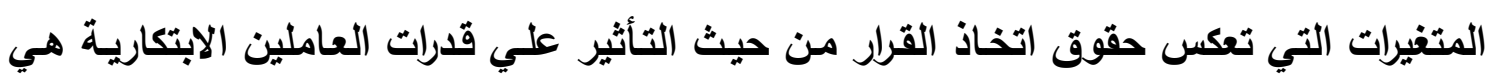

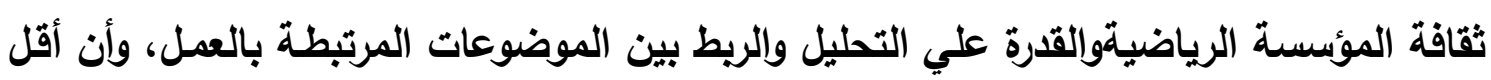

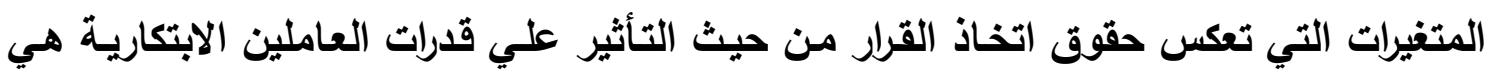

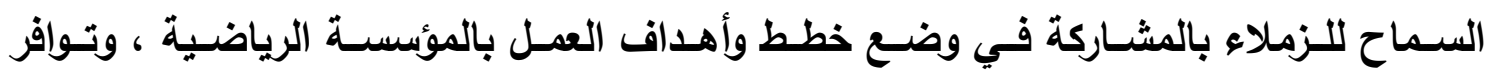

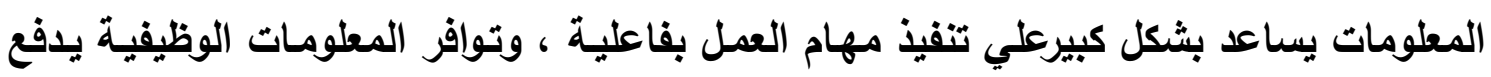

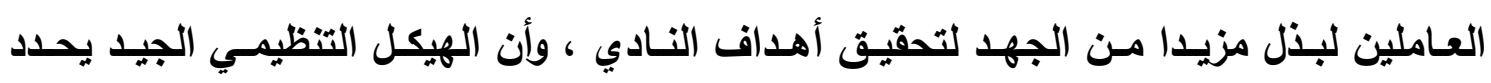

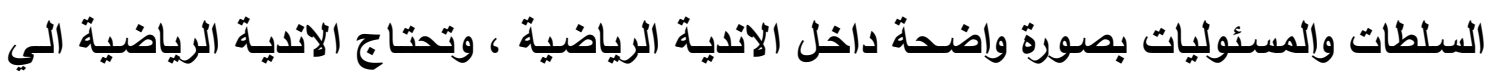
توفير التوصيف الوظيفي للوظائف مما يساعد علي اختيار الوظيفة المناسبة للقرد داخل النادي. الكلمات المفتاحية : الجينات التنظيمية - القلارات الابتكارية -المؤسسات الرياضية .

(") مدرس بقسم الإدارة والترويح الرياضى بكلية التربية الرياضية - جامعة طنطا . $-V V-$ 


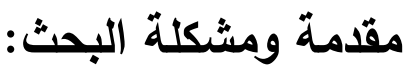

شهـدت السـنوات الأخيرة رؤيـة جديـدة للمنظمـات قائمـة على مفهوم الجينـات التنظيميـة Organizational DNA تتظيم المؤسسات لتحقيق غرض مشترك واحد واستراتيجية مشتركة، وكان أول من استخدم هذا

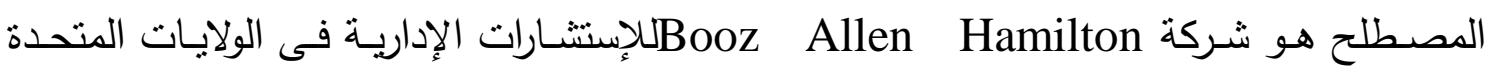
الأمريكية ، وقد عرفت نلك الثركة الجينات التظظيمية بأنه مصطلح مجازى يوضح العواملالأساسية

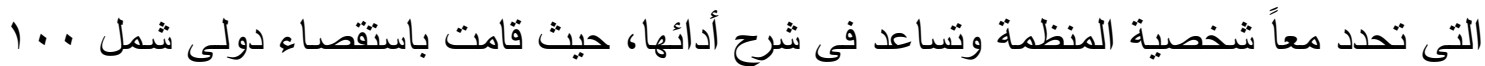
دولة، و ع ب قطاعا (كالقطاع المصرفى ، النقل وغيرها) و • ل إدارات مختلفة و 1 اقسام داخل

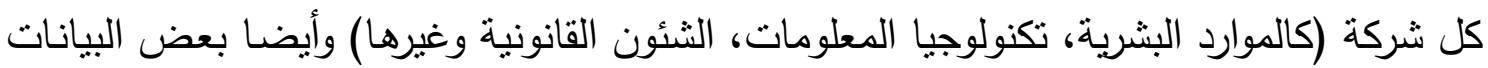

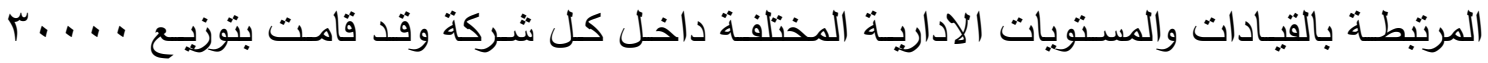

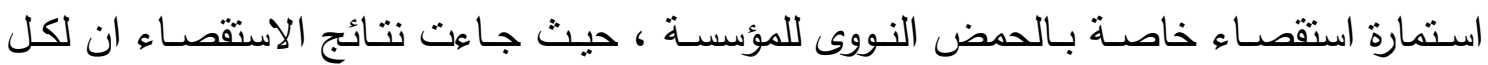

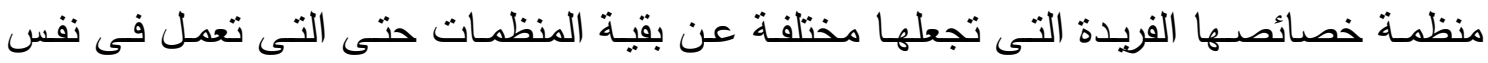

( Gera Surendera, Gu Wulong, 2004, 7) · المجال

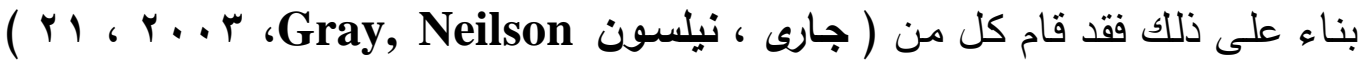

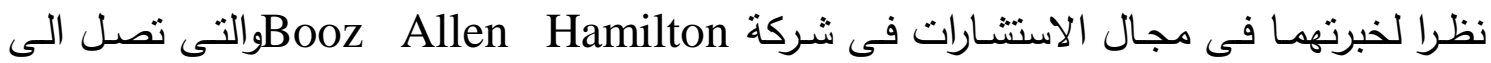
خمسين عاما إلى محاولة معرفة تلك الخصائص التى تمتل الحمض النووى للمنظمات والتى أمكن حصـرها فـى أربعـة متغيـرات هـي ( حقـوق اتخـاذ القرار - الدحفزات - المعلومـات - الهيكل

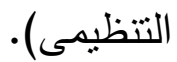

ومما سبق يتضح أن غرس القيم المناسبة فى العاملين بالمنظمة، ومنحهم الحوافز المناسبة

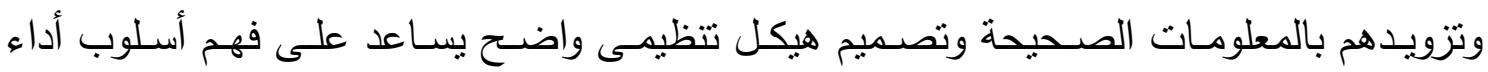
المنظمات بهدف تحديد المعوقات التى تحد من ممارستها لأنشطتها وتوفير سبل سهلة لمواجتها

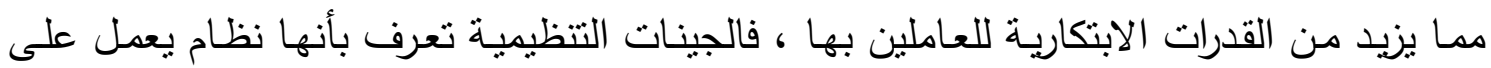

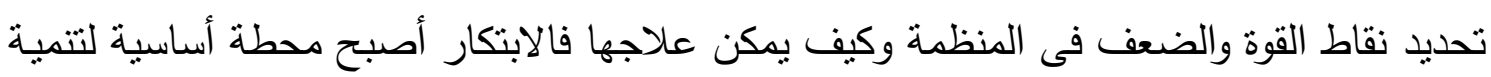

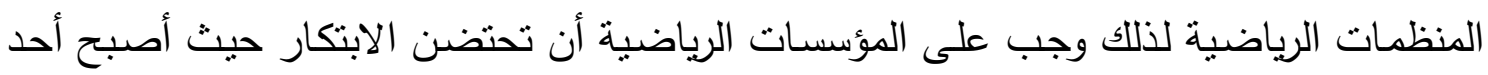

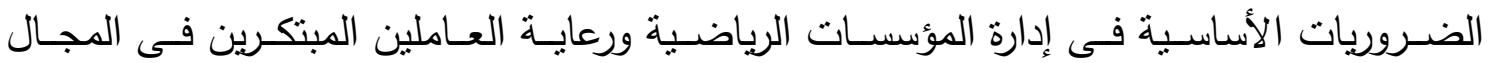

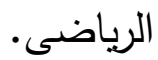




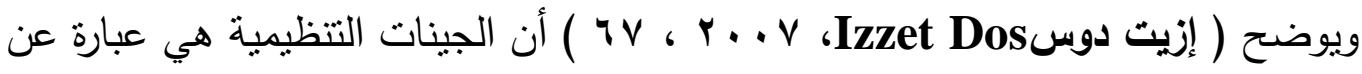

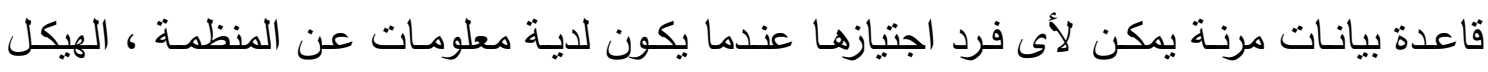
التظظيمى، الاجراءات والعلاقات بين العاملين فى المنظمة وبين الأفراد خارج المنظمة.

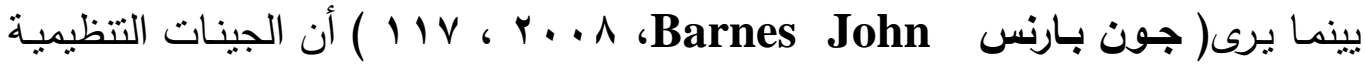

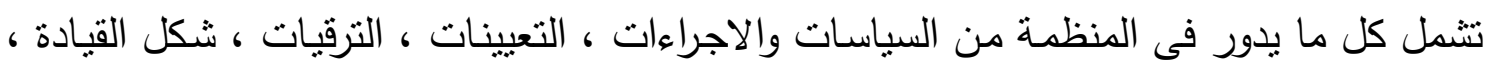

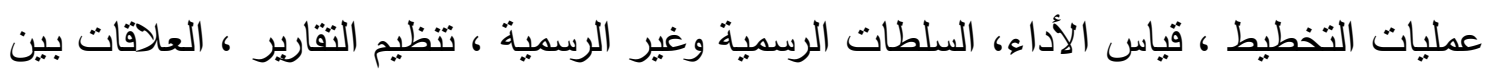
الأقسام والقيم الأساسية داخل المنظمة.

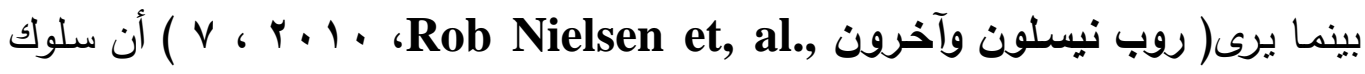
الأفراد هو الذى يحدد نجاح المنظمة فى كل وقت وأن الثركات الناجحة تتوقف على ولى وجود أفراد

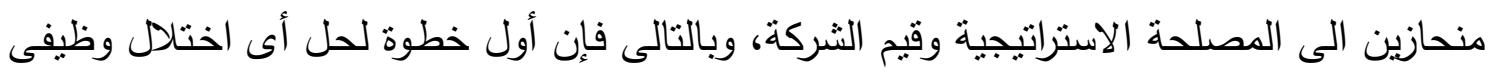

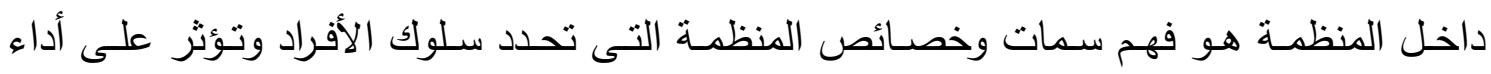
الأعمال وذلك عن طريق استخدام مفهوم Organizational DNA والذى يضع مجموعة من ونس الارشادات الدقيقة المطلوبة لخلق منظمة فريدة، والتى توضح ما هو سلوك المنظمة الداخلى وكيف يمكن انجازه وتقديمة للعملاء.

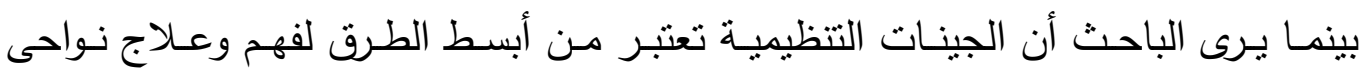

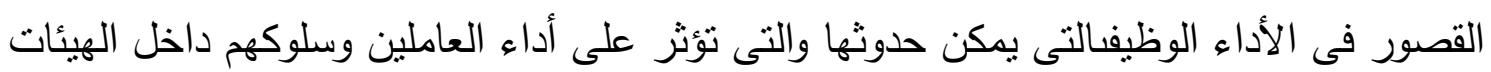
الرياضية.

ويشير ( إدوين بوز ، ألين هاميلتون Edwin Booz, Allen Hamilton، ج . . ب ،

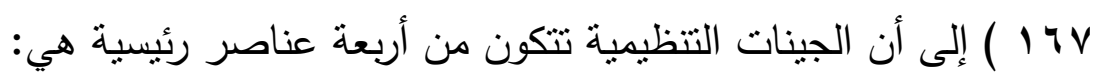

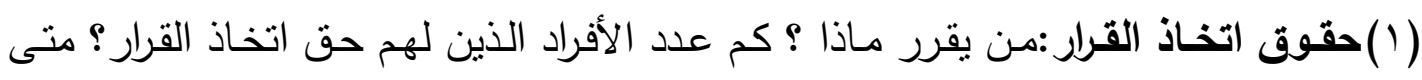

$$
\text { تتنهى سلطة اتخاذ القرار لشخص وتبدأ الأخرى؟ }
$$

(ץ)(المحفزات: ما هي الدوافع والحوافز التى تمتلكها المنظمة؟ وكيف يمكن مكافأة العاملين فى المنظمة على إنجازاتهج؟ كيف يمكن تتجيع الأفراد على الاهتمام بعملهم بطريقة مباشرة أو لهو

غير مباشرة؟

(r) المعلومات:ماهى المصفوفة المستخدمة لقياس الأداء؟ كيف يمكن تتظيم الأنثطة وتحويل المعلومات ؟ كيف يمكن تحويل المعلومات من الأفراد الذين يمتلكونها الى الأفراد الذين يحتاجونها ؟ من يعرف ماذا؟ ومن يحتاج إلى معرفة ماذا؟ 
(§) الهيكل التنظيمى: كيف ييدو الهيكل التتظيمى؟ كم عدد المستويات فى الهيكل التنظيمى ؟

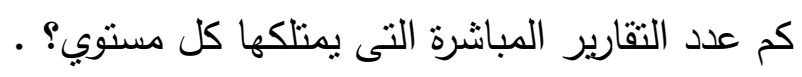

ويرى الباحث أن الابتكار الرياضى سوف يدعم المعرفة والتعليم والتدريب فى المؤسسات

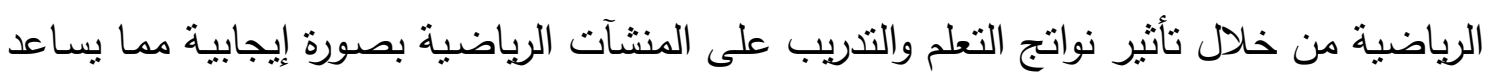
على تعزيز ثقافة الممارسة وكذلك الارتقاء بالمستويات النتافسية فى الألعاب المختلفة فلم بعد مقبولا أداء الأعمال فى المؤسسات الرياضية بالطرق الروتينية التقليدية فالإدارة.

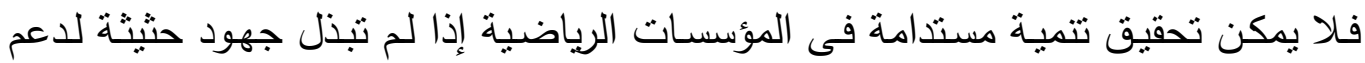
القدرات الابتكاريـة للدى العاملين بتلك المؤسسـات حتى تتـكن من مقاومـة المعوقـات الخارجيـة

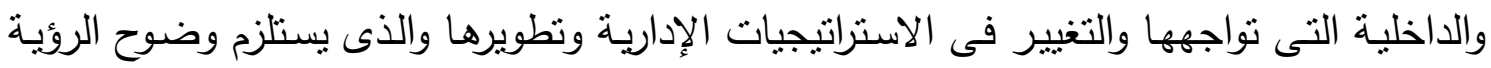

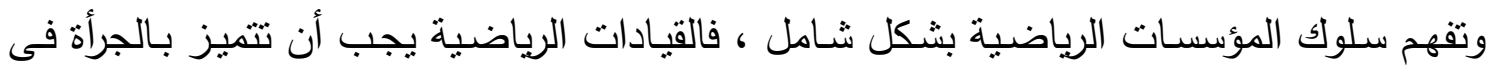

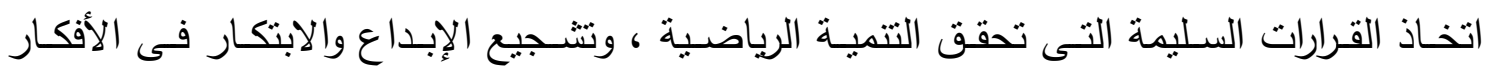

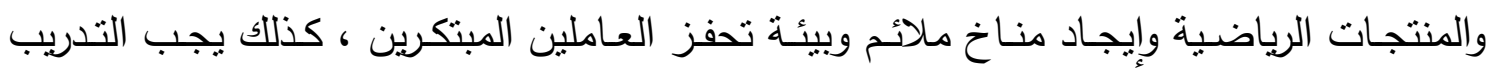

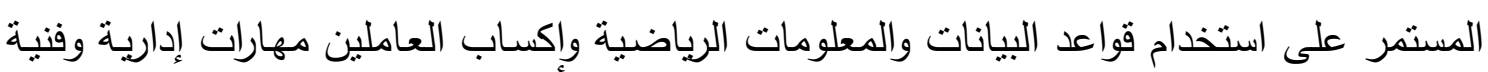
فى كيفية التعامل مع تلك المعلومات.

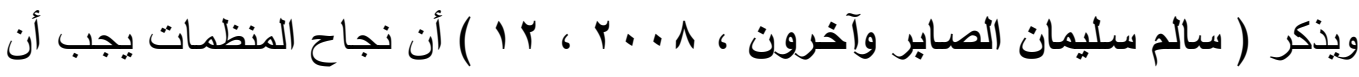

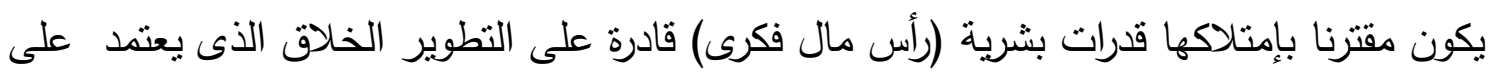

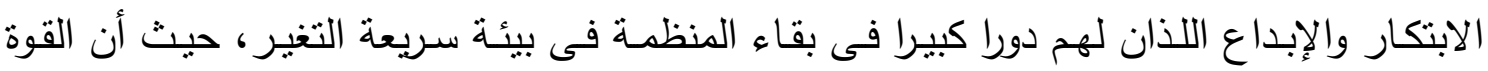

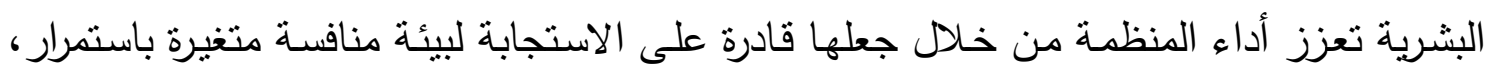

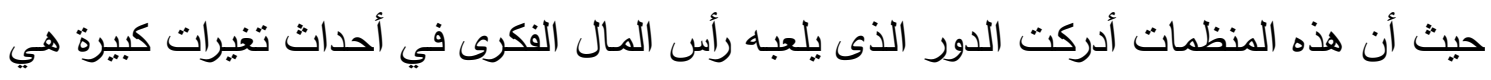
نتاج النشاط الفكربوالانسانفى المنظمة والذى يتصف بدرجة عالية من الإبداع والخلق والابتكار والتجديد.

كما قامت الأمم المتحدة عام 7 . . r بتعريف الابتكار الإدارفىى القطاع العام بأنه" قيام

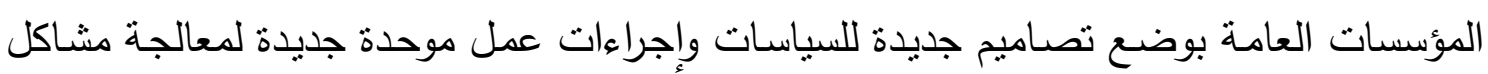
متعلقة بالسياسات العمومية ، أو أنه إيجاد حل ناجح وإبداعى وفريد لمشاكل جديدة أو حل جديد

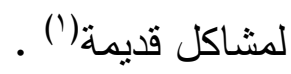
ويرى الباحث أن الابتكار الناجح يتوقف على بيئة عمل مرنـة فى اتخاذ القرارات وتوافر

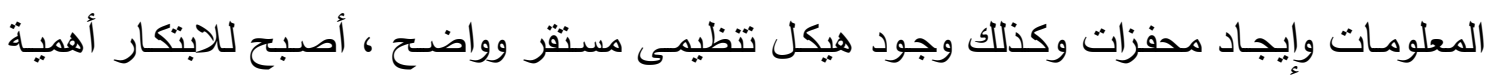


كبيرة فى ظل التحديات التى تواجهها المؤسسات الرياضية نتيجة الظروف المتغيرة فى العصر

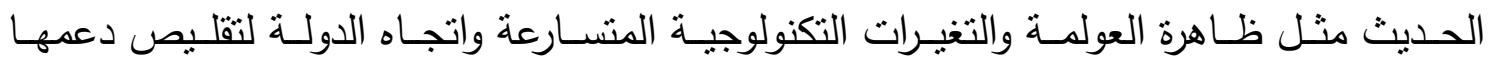
للمؤسسات الرياضية ودعم التوجه نحو التمويل الذاتى للمؤسسات الرياضية مما ينطلب خلق قدرات

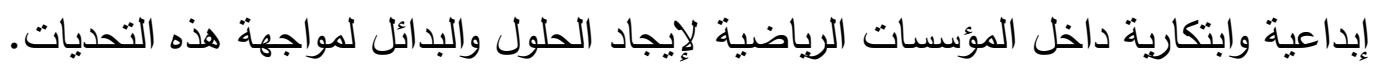

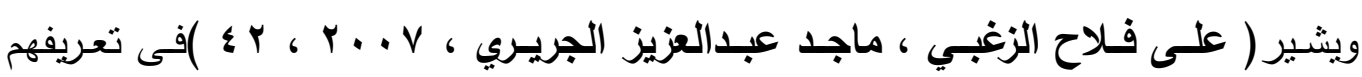

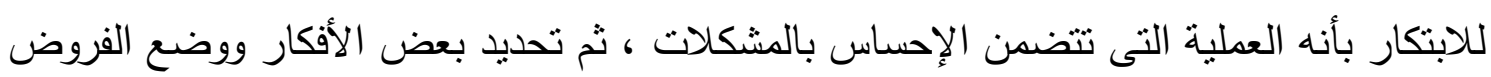
التى تعالج هذه المشكلات واختبار مدى صحة أو خطأ هذه الفروض وتوصيل النتائج إلى آخرين.

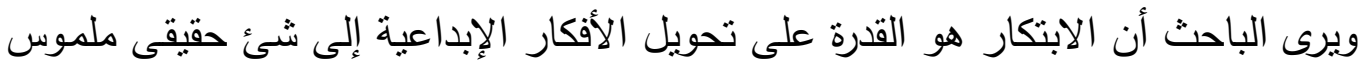

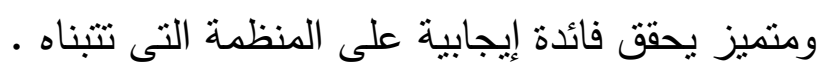

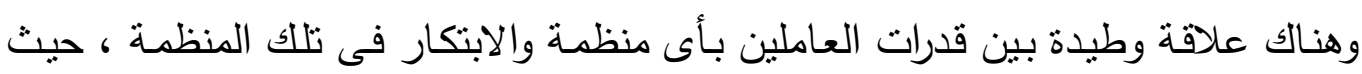

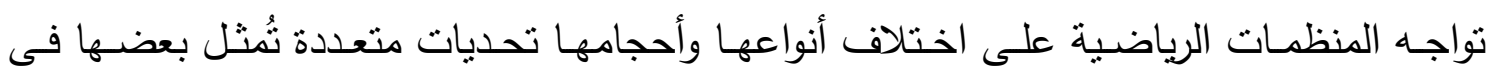

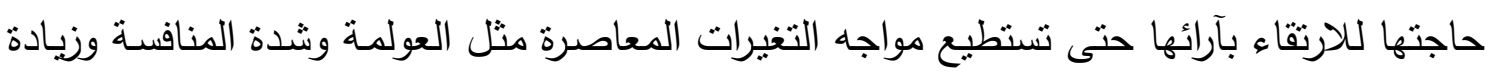

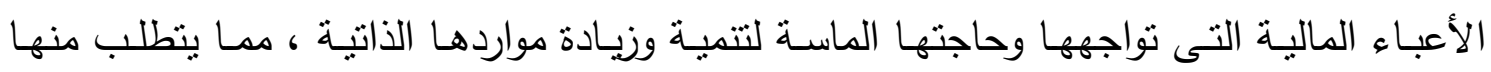

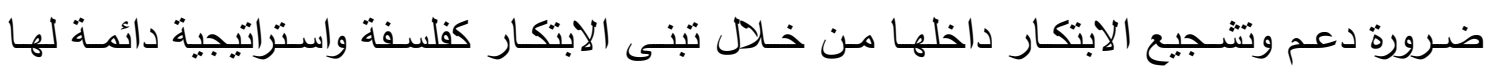
واكتثاف الأثخاص المبتكرين من العاملين بها من خلال الاهتمام بميول ودوافع ورغبات العاملين

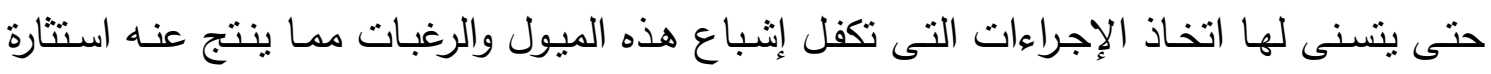
الجوانب الابتكارية لديهم مما يساعد على تحسين جودة وبيئة العمل ورفع مستوى الأداء لديهم .

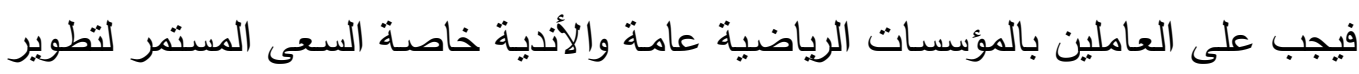

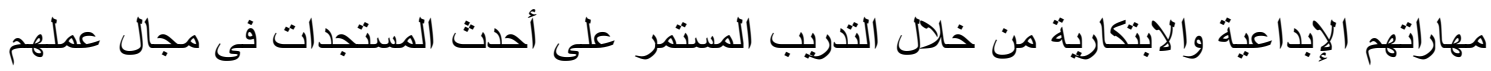

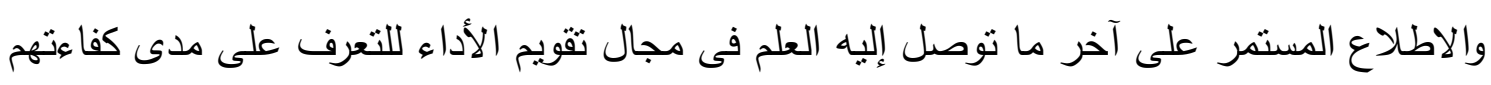

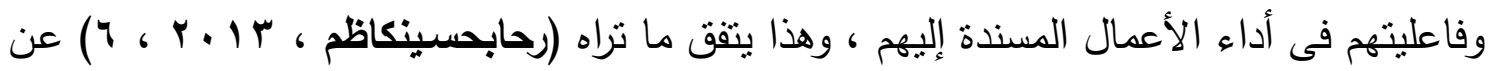
أنه يمكن قياس قدرات المرؤوسين فى المنظمة عن طريق " تقويم الأداء " وهى عملية تحليل لأداء

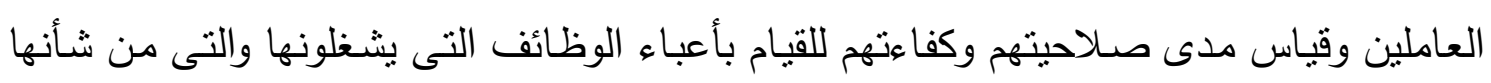

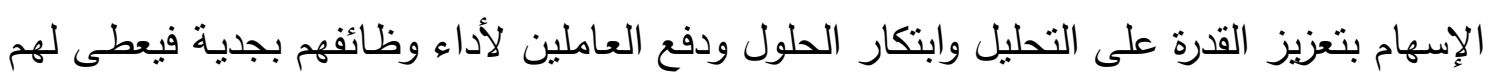
فرصة أكبر لظهور الإبداع والابتكار فى المنظمة والحصول على تقدير أعلى مما يكون له الأثر

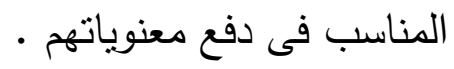


وقد أُجريت العديد من الدراسـات والبحـوث التى تتاولت العلاقـة بين العناصـر الأربعـة

للجينـات التتظيميـة (حقوق اتخـاذ القرار ، المحفزات ، المعلومـات ، الهيكل التتظيمس) والقدرات الابتكارية للعاملين ولكنها خارج المجال الرياضى، فنجد بعض الدراسات قد اتجهت إلى :

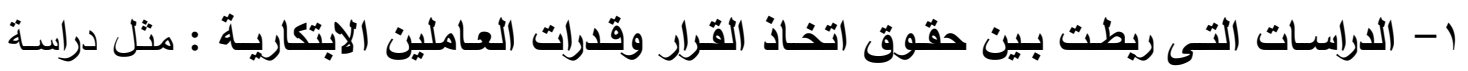
(محمد عبد التواب شاهين ، r . . ب)وموضوعها " الدعم التظظيمى وعلاقته بكل من عدالة التوزيع والمشاركة فى اتخاذ القرارات والكفاءة الاجتماعية " ، والتى توصلت إلى وجود علاقة معنوية موجبة بين عدالة الإجراءات ، كأحد عناصر الدعم التنظيمى ، والقدرات الابتكارية

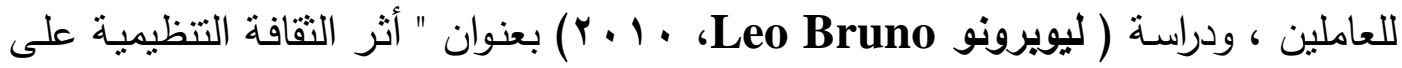
إدارة الابتكار " والتى نوصلت إلى بعض النتائج أهمها أن ثقافة المنظمة يكون لها دور كبير

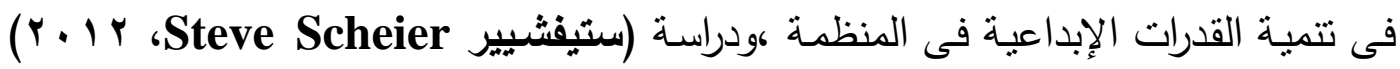
بعنوان "وضوح القرار بدفع الابتكار ويدعم المسئولية الاجتماعية وتحسين القيمة على المدى الطويل " ، والتى توصلت إلى بعض النتائج منها أن الغموض في عملية انخاذ القرار يؤثر بشكل كبير على كفاءة العطليات التى تتت فى المنظمة وكذللك يؤدى إلى عدم كفاءة أداء

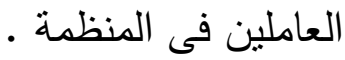
r- الاراسـات التى ريطت بين المحفزات والقدرات الابتكاريـة للعاملين :مثل دراسـة(أحمدقر

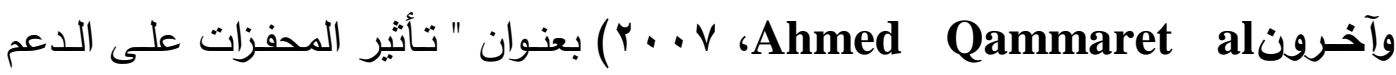
التتظيمى ودوافع العاملين " ، وقد توصلت الدراسة إلى بعض النتائج منها أنه هناك تأثثر معنـوى قـى بـين المحفزات والقدرات الابتكاريـة مـن خـلال الـدعم التنظيمى للعـاملين ، ودراسة(فلاديميربيروفيتش ، جوردانا كومازيك Vladimir Perović and Gordana

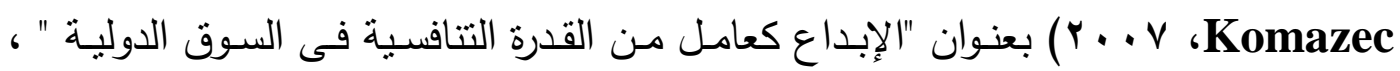
والتى توصلت إلى أن العاملين يتأثرون بالحوافز المعنوية بشكل كبير وتزداد لديهم القدرة على الابتكار بالمقارنة بزملائهم الذين لا تتوافر لدتهم تلك الحوافز حيث أنهم يميلون إلى لى

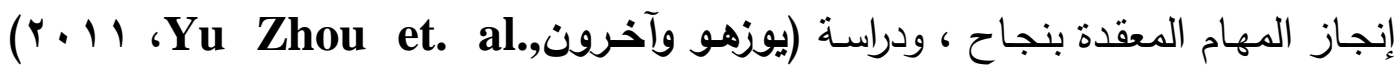
بعنوان " ثأثير المكافأت على السلوك المبتكر للموظفين " ، وتوصلت إلى بعض النتائج منها أن هناك علاقة إيجابية بين الحوافز الداخلية والخارجية وسلوك العاملين الابداعى . 
r- دراسات ريطت بين جودة المعلومـات والقدرات الابتكاريـة للعاملين: مثل (دراسـة جيرا ، جو Gera \&Gu

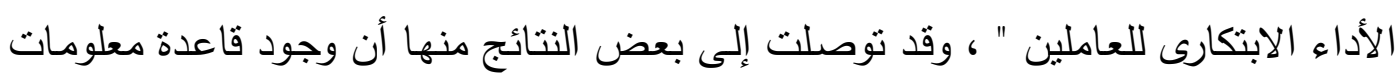

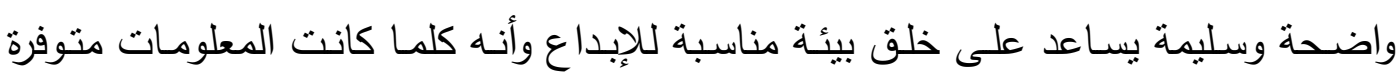
ومتاحة بشكل كبير مع وجود تتظيمات مرنة فى العمل كلما زادة القدرات الإبداعية للعاملين ، ودراسة (كلاى ديبريلا وآخرون Clay Dibrellet al 1 A . . ب)بعنوان " تعزير الابتكار من خلال تكنولوجيا المعلومات فى الثركات الصغيرة والمتوسطة " ، حيث بينت تلك الدراسة أنه عندما تتوافر للعاملين فى المنظمة معلومات كافية عن نواحى العمل داخل المنظمة وخارجها يؤدى هذا بشكل كبير إلى زيادة وتحفيز القدرات الابتكارية لهؤلاء العاملين ، وأنه هناك علاقة هوته قوية بين توافر المعلومات وقدرات العاملين الابتكارية .

ع- دراسات ريطت بين الهيكل التنظيمى وقدرات العاملين الابتكارية :مثل دراسة(أندريافاونا ،

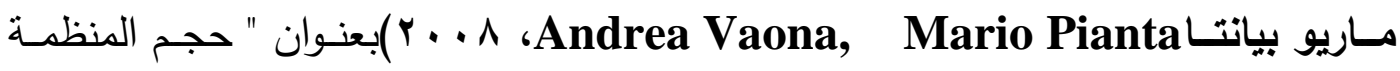
والابتكار فى الصناعة الأوربية" ، وقد توصلت تلك الدراسة إلى أن المنظمات كبيرة الحجم تتضح بها القدرات الإبداعية للعاملين بشكل أكبر من الثركات الصغيرة والمتوسطة الحجم حيث يسعى جميع العاملين إلى تتمية مهاراتهم وقدراتهم وذللك لتحقيق ميزة تتافسية عن بقية زملائهم ، ودراسة (فلاديمير بيروفيتش ، جوردانا كومازيك Vladimir Perović and

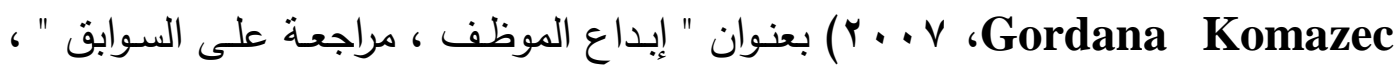
واستهدفت معرفة مـا هو أثر نطاق الإثـراف على القدرة الإنتاجية للعاملين بالمنظمات ، وتوصلت هذه الدراسة إلى بعض النتائج أهمها أن نطاق الإثراف الواسع كأحد سمات الهيكل التنظيمية له نأثثير معنوبإيجابى على القدرات الابتكارية للعاملين بالمنظمة ، وأنه كلما كانت المنظمة أصغر تزداد القدرة الابتكارية للعاملين بها بشكل أفضل وذلك بسبب سهولة الاتصال والدعم الإدارى بـين المديرين والعـاملين ، ودراسـة(بورديـا وآخـرون al Bordia et al ه . . ب)وهدفت هذه الدراسـة النظريـة إلى معرفـة مـا هـو أثر متغيرات الجينـات التتظيميـة مجمعة وهم (حقوق اتخاذ القرار ، المحفزات ، جودة المعلومات ، الهيكل التنظيهى) على قدرات المرؤوسين الابتكارية ، وتوصلت هذه الدراسة إلى بعض النتائج أهمها أنه توجد علاقة 
معنوية إيجابية بين عناصر الجينات التتظيمية مجمعة وتتمية قدرات العاملين الابتكارية ، وكذلك دراســة(أجراوالAgrawal عناصر Organizational DNA مجمعة وقدرات المرؤوسين الابتكارية حيث اهتمت هذه الدراسة بتحديد المتغيرات التى يتكون منها مفهوم الـOrganizational DNA وتأثير هذا المفهوم على تتميـة المهارات الإبداعيـة لهؤلاء المديرين وتوصلت هذه الدراسـة إلى بعض النتائج أههها أن حقوق اتخاذ القرار والمحفزات وجودة المعلومات لهم تأثنير على قدرات المديرين الابتكاريـة ، وأنه لبس هناك هيكل تتظيمى محدد ومعروف يمكن استخدامه فى قياس قدرات المرؤوسين الابتكاريـة بشكل عام ، وإنما يختلف الهيكل التنظيمى من شركة

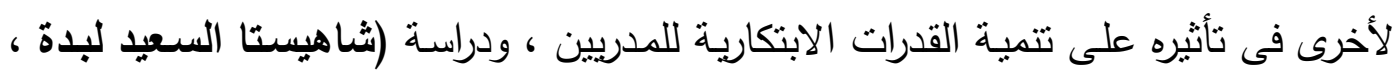

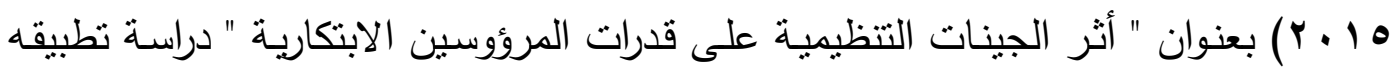
على البنوك التجارية بمصر ، والتى توصلت إلى عدم معنوية تأثير المشاركة فى اتخاذ القرار

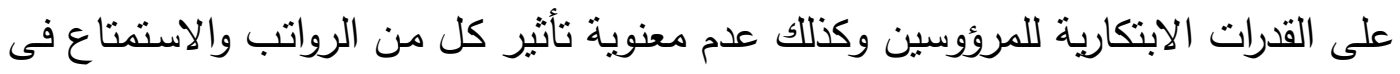
العمل على قدرات المرؤوسين الابتكارية وكذللك عدم معنوية تأثير مدى نوافر المعلومات على تلى

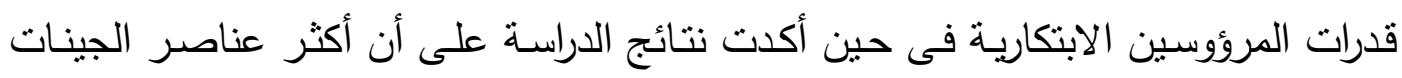
التتظيمية تأثيراً على قدرات المرؤوسين الابتكارية هو الهيكل التنظيميليه المحفزات ثم جودة

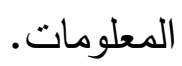

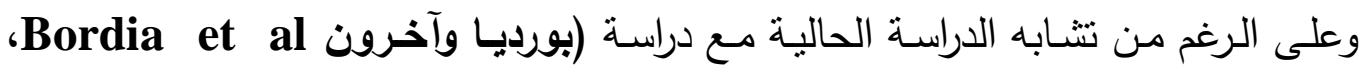

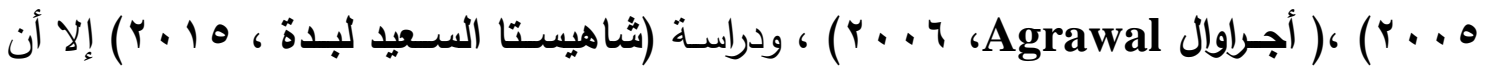
الدراسة الحالية تختلف عن الدراسات السابقفى العديدمن الدجالاتمثل مجال التطبيق حيث أهتمت وداله الدراسة الحالية بالتطبيق على المؤسسات الرياضية خاصة الأندية الرياضية لما لهذه الأندية من لألئل

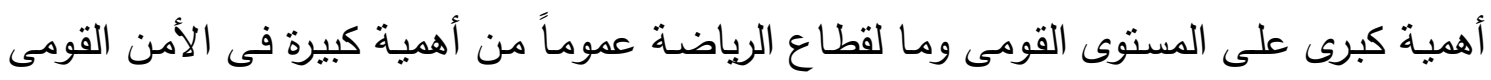
للبلاد .

لذا مما تقدم برى الباحث أن هناك ارتباط وثيق بين المتغيرات الأربعة للجينات التتظيمية

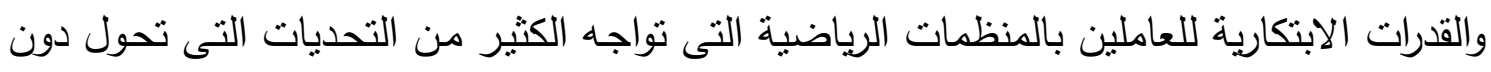

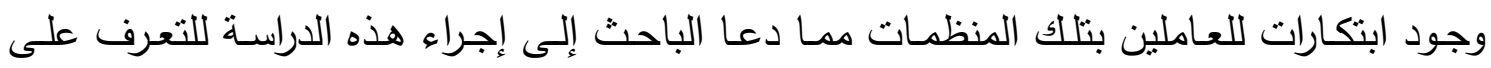
العلاقة بين الجينات التتظيمية والقدرات الابتكارية للعاملين بالمؤسسات الرياضية . 


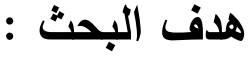

يحاول الباحث من خلال هذا البحث التعرف على العلاقة بين الجينات التتظيمية والقدرات

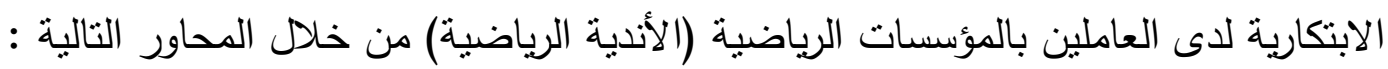

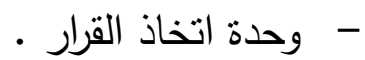

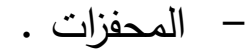

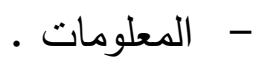

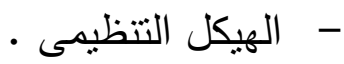

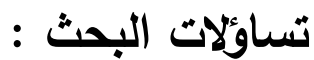

يحاول الباحث من خلال هذا البحث الإجابة على التساؤل التالى : ما هى العلاقة بين

الجينات التتظيمية والقدرات الابتكارية للعاملين بالمؤسسات الرياضية ؟

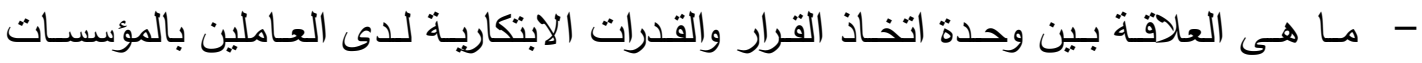

$$
\text { الرياضية؟ }
$$

- - ما هى العلاقة بين المحفزات والقدرات الابتكارية لاى العاملين بالمؤسسات الرياضية؟ - ما هى العلاقة بين المعلومات والقدرات الابتكارية لدى العاملين بالمؤسسات الرياضية؟ هل - - مـا هـى العلاقـة بـين الهيكل التنظيهى والقدرات الابتكاريـة لـدى العـاملين بالمؤسسـات

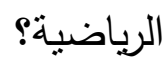

$$
\text { مصطات البحث : البهات : }
$$

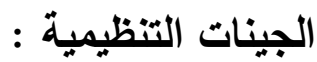

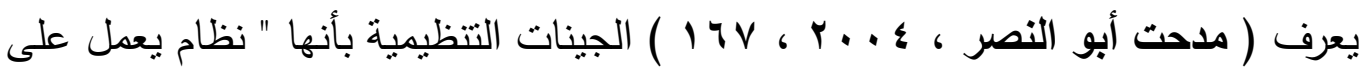
تحديد نقاط القوة والضعف فى المنظمة وكيف يمكن علاجها " .

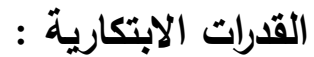

يعرف( مدحت أبو النصر ، ؛ . . . ، ، ) القدرات الإبتكارية بأنها " القدرة على الابتكار

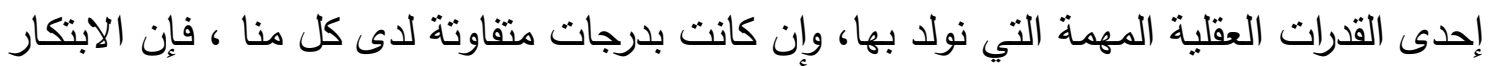

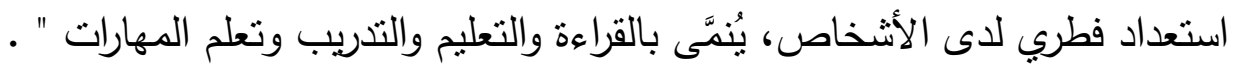

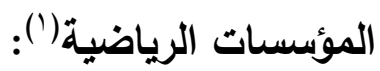

\footnotetext{
${ }^{(1)}$ http://www.aoulef.com/t1110-topic.
} 
مؤسسـات ينشئها المجتمع لخدمة القطاع الرياضى من كافة الجوانب، بحيث يكون لها

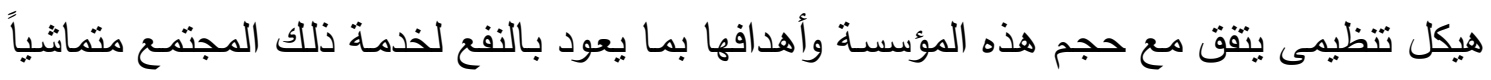

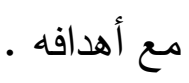

\section{إجراءات الدراسة :}

منهج الدراسة :

اعتمد الباحث على المنهج الوصفى بأسلوب الدراسات المسحية لمناسبته لطبيعة الدراسة الحالية .

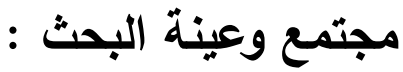

\section{مجتمع البحث :}

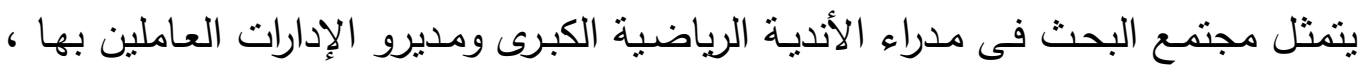

وقد قام الباحث بتحديد الأندية الرياضية الكبرى التى يتوافر بها الثروط الآتية :

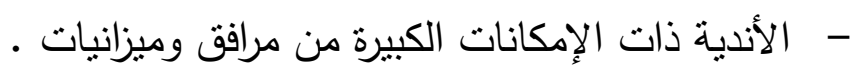

- الأندية ذات الأنشطة المتعددة .

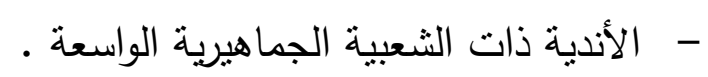

عينة البحث :اختار الباحث عينة البحث بالطريقة العشوائية وعددها (. . (1) فرداً من مدراء

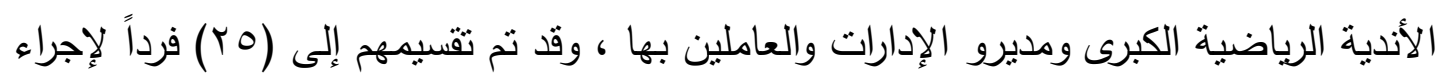
الدراسة الاستطلاعية وحساب المعاملات العلمية (الصدق والثنات) فقط ، ونم استبعادهم من العينة

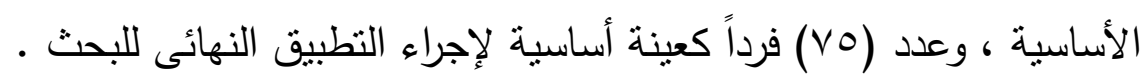

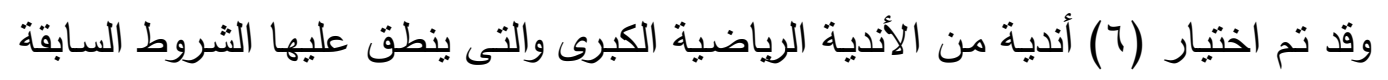

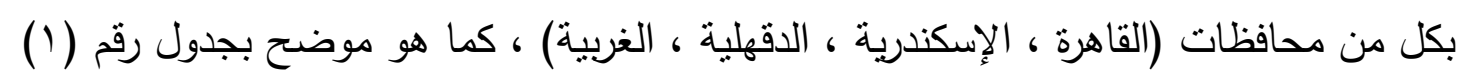

جدول (1)

توصيف عينة البحث

\begin{tabular}{|c|c|c|c|c|c|}
\hline \multirow{2}{*}{ الإجمالى } & \multicolumn{3}{|c|}{ العينة } & \multirow{2}{*}{ اسم النادى } & \multirow{2}{*}{ p } \\
\hline & العاملين & مديرو الإدارات & مدير النادى & & \\
\hline 17 & 1. & 0 & 1 & الأهلى & 1 \\
\hline r. & 10 & $\varepsilon$ & 1 & طنطا & r \\
\hline 9 & 0 & $r$ & 1 & نادى غزل المحلة & $r$ \\
\hline 11 & 0 & 0 & 1 & الاتحاد السكندرى & $\varepsilon$ \\
\hline 7 & $r$ & $r$ & 1 & المنصورة & 0 \\
\hline 15 & 0 & $v$ & 1 & الجزيرة & 7 \\
\hline vo & $\leqslant r$ & YV & 7 & الإجمالى & \\
\hline
\end{tabular}


قام الباحث بإعداد استبيان بهدف التعرف على العلاقة بين الجينات التتظيمية والقدرات

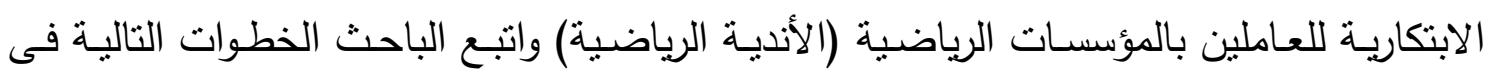

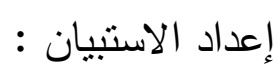
- الصدق المنطقى لإستمارة الإستبيان :

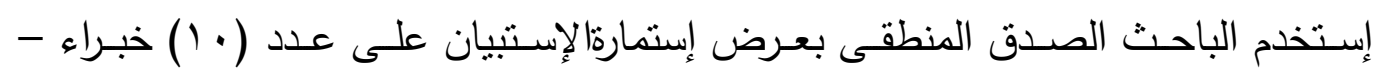

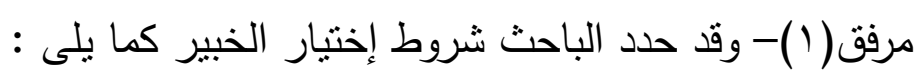
ا أن يكون عضو هيئة تدريس (1)

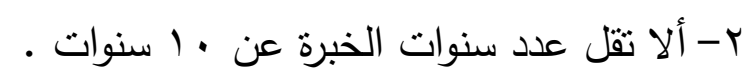

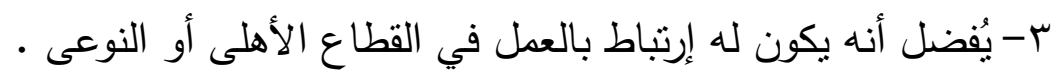

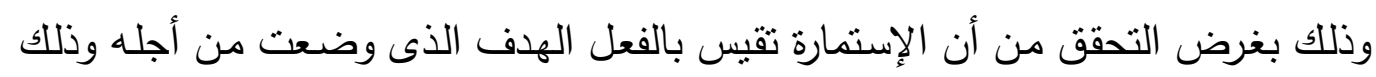

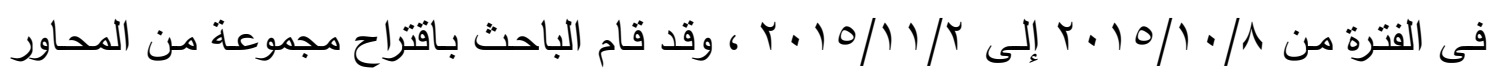

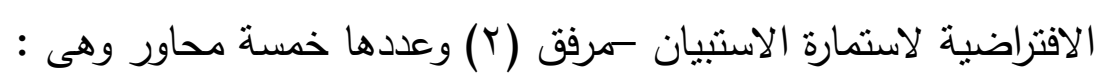
- وحدة اتخاذ القرار - جودة المعلومات - الهيكل التتظيمى - القدرات الابتكارية للعاملين . وقد قام الباحث بعرض المحاور الافتراضية على السادة الخبراء مستخدماً فى ذلك مقياساً

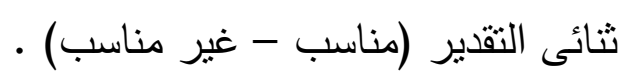

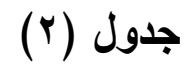

التكرار والنسبة المئوية والأهمية النسبية لآراء السادة الخبراء حول محاور استمارة استبيان

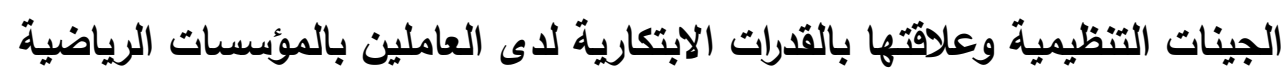
ن

\begin{tabular}{|c|c|c|c|c|c|c|c|}
\hline \multirow{2}{*}{ النسبية } & \multirow{2}{*}{ النسبي } & \multicolumn{2}{|c|}{ لاواوافق } & \multicolumn{2}{|c|}{ أوافق } & \multirow{2}{*}{ المحاور } & \multirow[t]{2}{*}{ r } \\
\hline & & $\%$ & 5 & $\%$ & 5 & & \\
\hline $1 \ldots \ldots$ & 1. & $\because \cdots$ & . & $1 \ldots$. & 1. & وحدة اتخاذ القرار & 1 \\
\hline $1 \ldots$ & 1. & $\because \cdots$ & - & $1 \ldots$. & 1. & المحفزات & $r$ \\
\hline $1 \cdots \cdots$ & 1. & $\because \cdots$ & $\cdot$ & $1 \cdots \cdot \cdots$ & 1. & المعلومات & $r$ \\
\hline $1 \cdots \cdot \cdots$ & 1. & $\because \cdots$ & $\cdot$ & $1 \cdots \cdot \cdots$ & 1. & الهيكل التنظيمى & $\varepsilon$ \\
\hline $9 . . \cdots$ & 9 & $1, \ldots$ & $T$ & $9 \cdot \ldots$ & 9 & السلوك الابتكارى & 0 \\
\hline
\end{tabular}

يوضـح جدول (r) التكرار والنسبة المئويـة والوزن النسبي والأهميـة النسبية لآراء السـادة الخبراء حـول محـاور استبيان الجينـات التتظيميـة وعلاقتهـا بالقدرات الابتكاريـة لـدى العـاملين

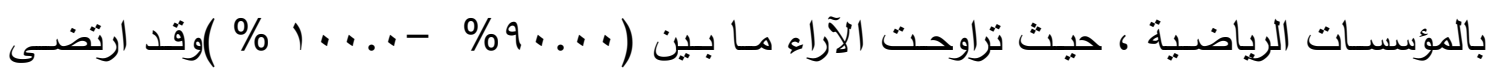

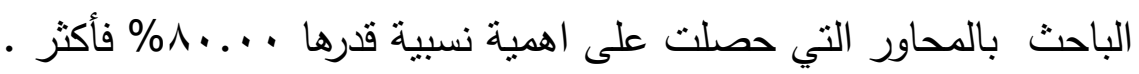


ثم قـام الباحث بصـياغة مجموعـة مـن العبارات بكل محسور حيث بلـن عدد العبـارات

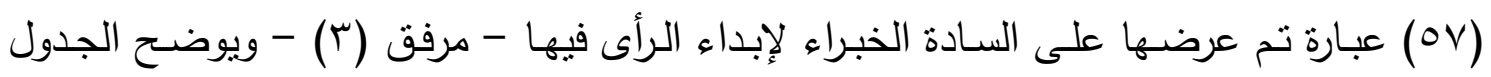
(r ) النسبة المئوية لآراء السادة الخبراء حول عبارات محاور استمارة استبيان الجينات التنظيمية وعلاقتها بالقدرات الابتكارية لدى العاملين بالمؤسسات الرياضية.

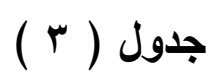

النسبة المئوية لآراء السادة الخبراء حول عبارات محاور استمارة استبيان الجينات التظيمية

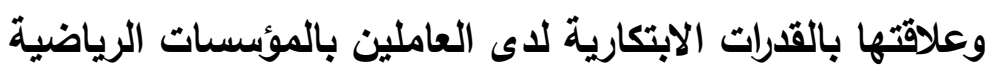

ن

\begin{tabular}{|c|c|c|c|c|c|c|c|c|c|}
\hline \multicolumn{2}{|c|}{ المحور السادس } & \multicolumn{2}{|c|}{ المحور الرابع } & \multicolumn{2}{|c|}{ المحور الثالث } & \multicolumn{2}{|c|}{ المحور الثانى } & \multicolumn{2}{|c|}{ المحور الأول } \\
\hline نسبة المو افقة & b & نسبة الموافقة & b & نسبة الموافقة & r & نسبة الموافقة & p & نسبة الموافقة & م \\
\hline$\Lambda \cdot \ldots$ & 1 & $\Lambda . .$. & 1 & $1 \ldots, \cdots$ & 1 & $9 \cdot \ldots$ & 1 & $1 \ldots$ & 1 \\
\hline $1 \ldots$ & $r$ & $9 . \ldots$ & $r$ & $9 \cdot \ldots$ & $r$ & $1 \ldots$ & r & $1 \ldots$ & $r$ \\
\hline $9 \cdot \ldots$ & $r$ & $1 \ldots$ & $r$ & $9 \cdot \ldots$ & $r$ & $\Lambda \cdot \ldots$ & $r$ & $9 \cdot \ldots$ & $r$ \\
\hline $1 \ldots$ & $\varepsilon$ & $0 \cdot \ldots$ & $\varepsilon$ & $1 \ldots$ & $\varepsilon$ & $\Lambda \cdot . \cdots$ & $\varepsilon$ & $1 \ldots$ & $\varepsilon$ \\
\hline $1 \ldots$ & 0 & $1 \ldots$ & - & $\wedge . . \cdots$ & 0 & $1 \ldots$ & • & $1 \ldots \ldots$ & 0 \\
\hline$\Lambda \cdot . \cdots$ & 7 & $\varepsilon \cdot \ldots$ & 7 & $9 \cdot \ldots$ & 7 & $7 . \ldots$ & 7 & $\Lambda \cdot . \cdots$ & 7 \\
\hline $1 \cdots \cdots$ & $V$ & $9 \cdot \ldots$ & $V$ & $1 \ldots$ & $V$ & $1 \cdots, \cdots$ & $\mathrm{V}$ & $9 . \ldots$ & $\mathrm{V}$ \\
\hline $0 \cdot \ldots$ & $\Lambda$ & $1 \ldots$ & $\Lambda$ & $1 \ldots$ & $\Lambda$ & $9 . .$. & $\Lambda$ & $1 \cdots$, & $\Lambda$ \\
\hline $9 \cdot \ldots$ & 9 & $1 \ldots$ & 9 & $\Lambda \cdot . \cdots$ & 9 & $1 \ldots$. & 9 & $0 \cdot \ldots$ & 9 \\
\hline $1 \ldots \ldots$ & 1. & $1 \ldots$ & 1. & $9 . \ldots$ & 1. & $9 . \ldots$ & 1. & $9 . . \cdots$ & 1. \\
\hline $1 \ldots$ & 11 & $7 . \ldots$ & 11 & & & $1 \ldots$ & 11 & $\varepsilon \cdot \ldots$ & 11 \\
\hline & & $\Lambda \cdot \ldots$ & Ir & & & & & $1 \ldots$ & Ir \\
\hline & & $1 \ldots$. & 14 & & & & & & \\
\hline
\end{tabular}

يوضـح جدول (r)النسبة المئويـة لآراء السـادة الخبراء حول عبـارات استبيان الجينات

التنظيمية وعلاقتها بالقدرات الابتكارية لاى العاملين بالمؤسسات الرياضية ، ويتضح تراوح النسبة لارية

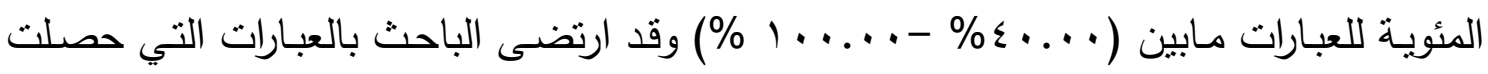

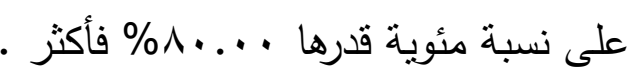

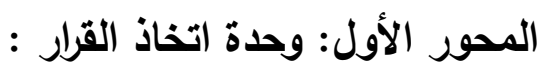

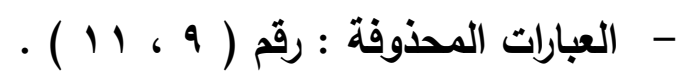

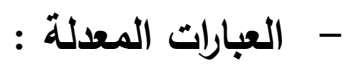

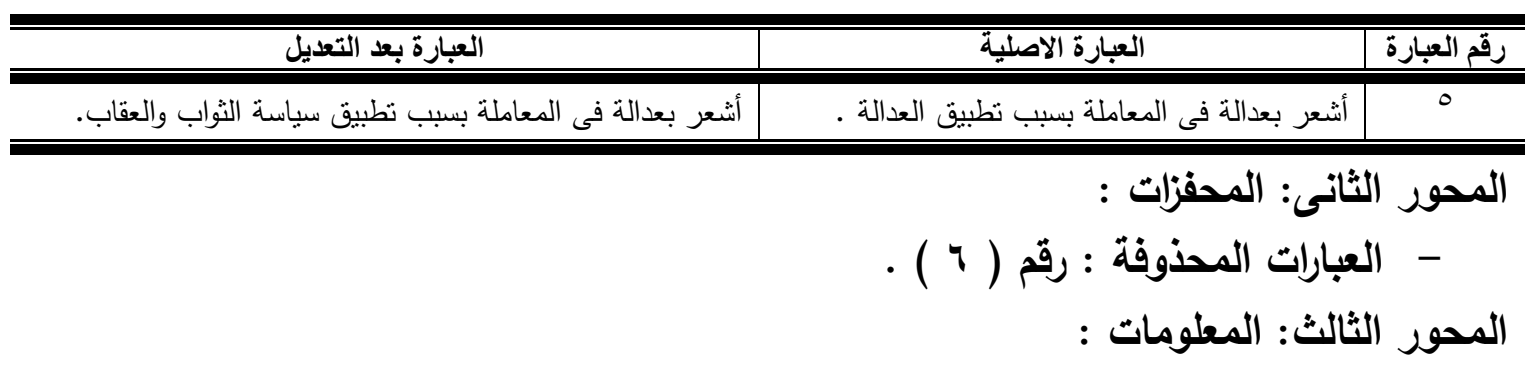




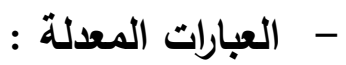

\begin{tabular}{|c|c|c|}
\hline العبارة بعد التُعديل & العبارة الاصلية & رقمّم العبارة \\
\hline أهداف النادى. تولومات الوظيفية يدفعنى لبذل مزيد من الجهد لتحقيق & 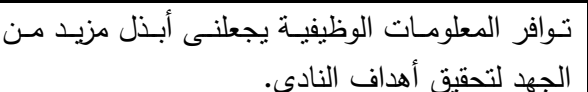 & $\varepsilon$ \\
\hline & \multicolumn{2}{|c|}{ العبارات الم } \\
\hline \multirow[t]{2}{*}{ يوجد نظام متكامل للمعلومات بالنادى الذى أعمل به } & يوجد تكامل للمعلومات بالنادى الذى أعمل به & V \\
\hline & 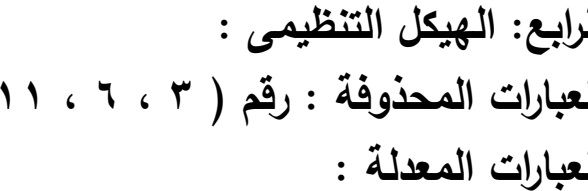 & المحور | \\
\hline العبارة بعد التعديل & العبارة الاصلية & العبارة \\
\hline الإدارة العليا للنادى تعمل على تلطوير ومرونـة & 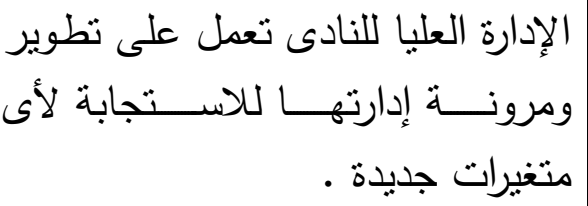 & $\Lambda$ \\
\hline
\end{tabular}

المحور الخامس: عناصر تعكس قرات العاملين الإبتكارية :

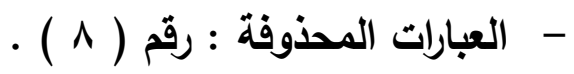

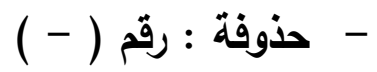

جدول (๕)

العدد المبئي والنهائي وأرقام العبارات المستبعدة لاستمارة استبيان الجينات التنظيمية وعلاقتها

بالقدرات الابتكارية لاى العاملين بالمؤسسات الرياضية

\begin{tabular}{|c|c|c|c|c|c|c|c|}
\hline اللعباراتي & العبارَاتِ & العبارات & أرقام العبارات & المبنتبعدة & للعباراتي & المحاور & p \\
\hline 1. & 0 & 1 & $11-9$ & $r$ & ir & وحدة اتخاذ القرار & 1 \\
\hline 1. & . & . & 9 & 1 & 11 & المحفزات & $r$ \\
\hline 1. & $V-\varepsilon$ & $r$ & - & . & 1. & المعلومات & $r$ \\
\hline 1. & $\wedge$ & 1 & $11-9-r$ & $r$ & 14 & الهيكل التنظيمى & $\varepsilon$ \\
\hline 1. & - & . & $\wedge$ & 1 & 11 & السلوك الابتكارى & 0 \\
\hline o. & $\varepsilon$ & $\varepsilon$ & v & $v$ & ov & الإجمالي & \\
\hline
\end{tabular}

التظيمية وعلاقتها بالقدرات الابتكارية لدى العاملين بالمؤسسات الرياضية ، ويتضـح اتفاق السادة

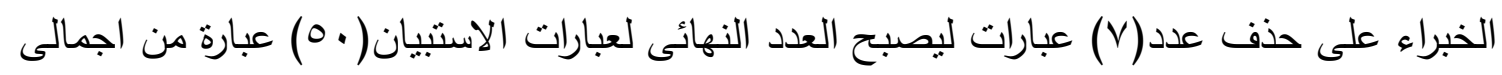

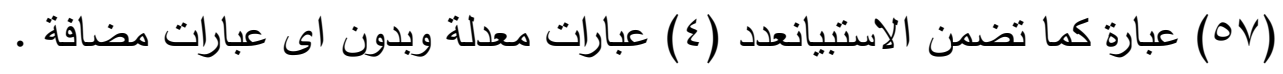
- صدق الإتساقالا خلإِستمارة|الإستبيان: 
قـام الباحث بحسـاب معامـل صـدق الإتساقالداخلـلإستمارةالإسـتبيان عن طريـق تطبيـق

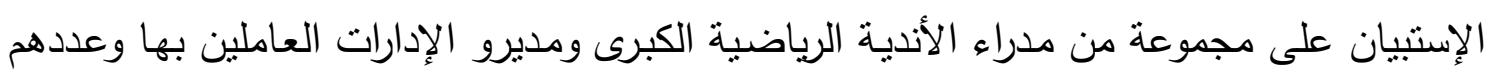

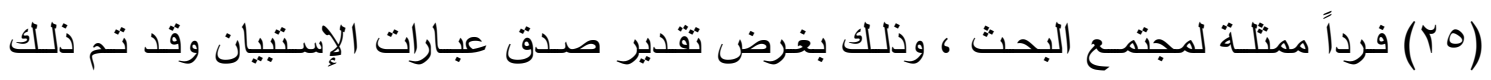
بحساب معاملات الإرتباط بين كل عبارة والمحور وبين كل عبارة والمجموع الكلى للمحاور وبين

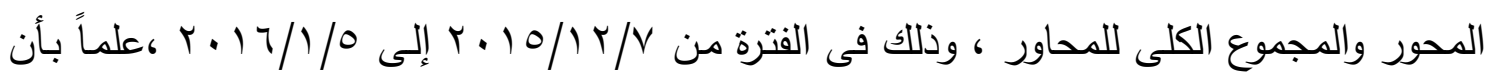

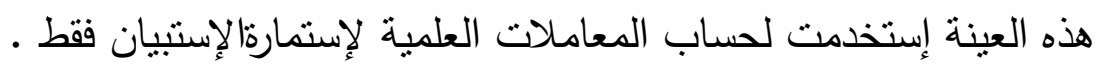

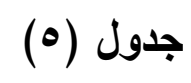

صدق الاتساق الداخلى بين العبارة والمحور ويين العبارة والمجموع الكلى لاستمارة استبيان

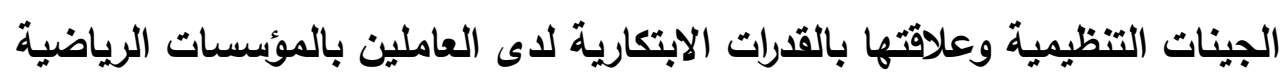
$r \bullet=\dot{U}$

\begin{tabular}{|c|c|c|c|c|c|c|c|c|c|c|c|c|c|c|}
\hline \multicolumn{3}{|c|}{ المحور الخامس } & \multicolumn{3}{|c|}{ المحور الرابع } & \multicolumn{3}{|c|}{ المحور الثالث } & \multicolumn{3}{|c|}{ المحور الثُانى } & \multicolumn{3}{|c|}{ المحور الأول } \\
\hline المجعِ & المعِ & م & المجعِ & المعِ & r & العمعِ & العمّارة & p & العبّم & المعِ & b & المجّم & العمع العبارة & b \\
\hline.$\wedge 4$ & $\because 9 r$ & 1 & $\because \wedge q$ & .91 & 1 & $\because \wedge \mathrm{V}$ & $\because 9$ & 1 & $\because \wedge \mathrm{V}$ & $\cdot . \wedge r$ & 1 & $\because \wedge \vee$ & $\because 94$ & 1 \\
\hline$\cdot \wedge \theta$ & .91 & $r$ & .91 & $\cdot . \wedge 7$ & $r$ & $\cdot . \wedge r$ & $\because \wedge \mathrm{V}$ & $r$ & $\cdot . \wedge \varepsilon$ & $\because \wedge 1$ & $r$ &. .17 &.$\wedge \varepsilon$ & $r$ \\
\hline..$\wedge 9$ & $\cdot . \wedge 7$ & $r$ & $\because \wedge \theta$ & $\cdot . \wedge \mathrm{V}$ & $r$ & $\cdot . \wedge r$ & $\cdot . \wedge \wedge$ & $r$ & .94 & $\cdot . \wedge \mathrm{V}$ & $r$ & $\cdot \wedge \varepsilon$ &.$\wedge \wedge$ & $r$ \\
\hline$\because 9$. & .94 & $\varepsilon$ & $\because \wedge \wedge$ & $\cdot . \wedge \varepsilon$ & $\varepsilon$ &.$\wedge 4$ & $\because 9$ & $\varepsilon$ & $\cdot . \wedge r$ & $\cdot . \wedge 9$ & $\varepsilon$ &.$\wedge \wedge$ & $\cdot . \wedge 0$ & $\varepsilon$ \\
\hline.$\wedge 0$ & $\cdot . \wedge$ & 0 & .91 & $\cdot . \wedge 9$ & 0 & $\because 9$ &.$\wedge r$ & 0 & $\cdot . \wedge 7$ & .9 & 0 & .9 & $\cdot . \wedge \varepsilon$ & 0 \\
\hline$\cdot . \wedge r$ & $\cdot . \wedge \mathrm{V}$ & 7 & $\cdot . \wedge \mathrm{V}$ &. .91 & 7 & $\cdot . \wedge 9$ & $\cdot \wedge$ & 7 & $\cdot . \wedge \varepsilon$ & $\cdot \wedge \mathrm{V}$ & 7 &..$\wedge 9$ &.$\wedge \mathrm{V}$ & 7 \\
\hline$\cdot . \wedge r$ &. .91 & $\mathrm{~V}$ & $\cdot . \wedge \wedge$ &. $.9 r$ & $\mathrm{~V}$ &.$\wedge r$ & $\cdot . \wedge \wedge$ & $\mathrm{V}$ & .99 & $\cdot . \wedge 7$ & $\mathrm{~V}$ & $\cdot . \wedge \varepsilon$ &.$V \varepsilon$ & $\mathrm{V}$ \\
\hline .91 & $\cdot . \wedge 7$ & $\Lambda$ & $\cdot . \wedge \varepsilon$ & $\cdot . \wedge r$ & $\Lambda$ & $\because \wedge \mathrm{V}$ & $\cdot . \wedge \varepsilon$ & $\Lambda$ & $\cdot . \wedge 7$ & $\cdot . \wedge \varepsilon$ & $\Lambda$ &.$\wedge 7$ & .91 & $\Lambda$ \\
\hline$\cdot . \wedge r$ & $\because \mathrm{V \Lambda}$ & 9 & .91 & $\cdot . \wedge \wedge$ & 9 & .94 & $\cdot . \wedge \theta$ & 9 & $\because \wedge V$ & $\cdot . \wedge \Gamma$ & 9 & $\therefore \wedge 9$ & $\therefore \wedge$ & 9 \\
\hline$\cdot \wedge \wedge$ & .9. & 1 &.$\wedge r$ & .9. & $\begin{array}{l}1 \\
\end{array}$ &.$\wedge r$ & $\because \vee \wedge$ & $\begin{array}{l}1 \\
\end{array}$ & .91 & $\cdot .^{\wedge}$ & ! & .94 & $\cdot . \wedge 7$ & $\begin{array}{l} \\
\end{array}$ \\
\hline
\end{tabular}

يوضح جدول (0) وجود ارتباط ذو دلالة إحصائية بين العبارة والمحور حيث تراوحت قيمة المبة

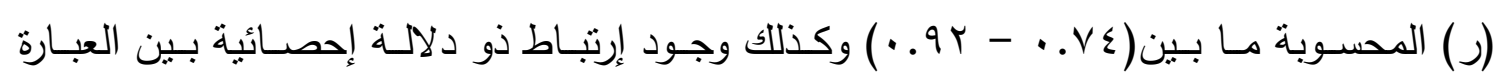

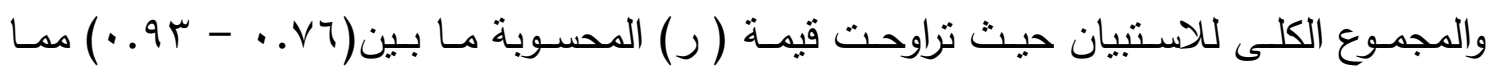

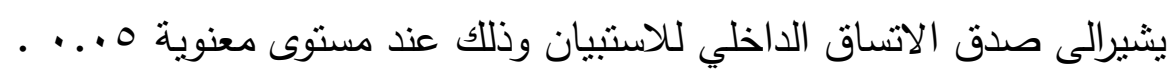

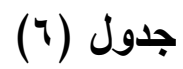

صدق الاتساق الااخلى بين المحور والمجموع الكلى لاستمارة استبيان الجينات التنظيمية وعلاقتها بالقدرات الابتكارية لاى العالملين العاتين بالمؤسسات الرياضية Yo $=0$

\begin{tabular}{|c|c|c|}
\hline معامل الارتباط & المحاور & $\overline{5}$ \\
\hline$\cdot . \wedge \mathrm{V}$ & وحدة اتخاذ القرار & \\
\hline$\because \wedge \Lambda$ & المحفزات & $r$ \\
\hline$\because .9$. & المعلومات & $T$ \\
\hline
\end{tabular}




\begin{tabular}{|c|c|c|}
\hline$\cdot . \wedge 7$ & الهيكل التنظيمى & $\varepsilon$ \\
\hline 9.91 & السلوك الابتكاري & 0 \\
\hline
\end{tabular}

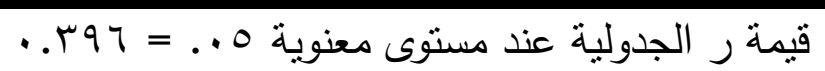

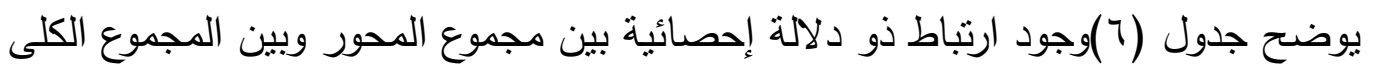

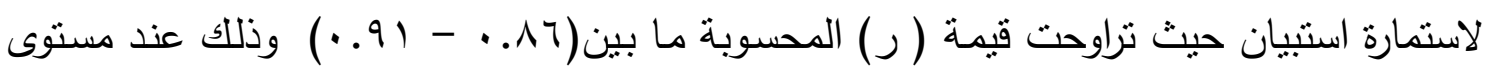

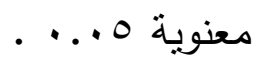

- ثبات إستمارة الإستبيان:

- حساب معامل الثبات عن طريق التطبيق وإعادة التطبيق Test - Retest: قام الباحث بتطبيق الإستمارة على مجموعة من مدراء الأنديـة الرياضية الكبرى ومديرو الإدارات العاملين بها وعددهم ( T ) فرداً ممثلة لمجتمع البحث ، وقد قام الباحث بإجراء التطبيق

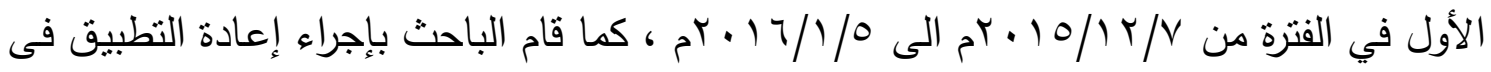

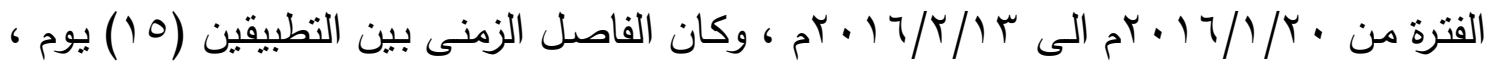

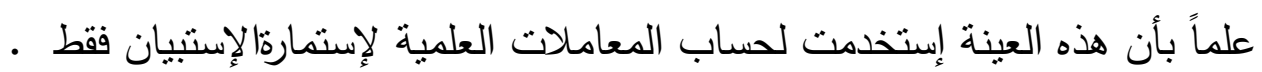
جدول (V)

معامل الارتباط بين التطبيق واعادة التطبيق لبيان معامل الثباتلاستمارة استبيان الجينات

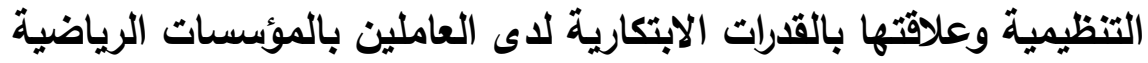

$Y \theta=\dot{0}$

\begin{tabular}{|c|c|c|c|c|c|c|c|c|c|}
\hline \multicolumn{2}{|c|}{ المحور الخامس } & \multicolumn{2}{|c|}{ المحور الرابع } & \multicolumn{2}{|c|}{ المحور التَالث } & \multicolumn{2}{|c|}{ المحور الثانى } & \multicolumn{2}{|c|}{ المحورالاول } \\
\hline الارتباط & P & معامل الارتباط & P & معامل الارتباط & 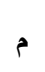 & معامل الارتباط & $p$ & معامل & $p$ \\
\hline .997 & 1 & $\cdot . \wedge \Lambda$ & 1 & $\cdot .19$ & 1 & .99 & $T$ &. .97 & $\bar{T}$ \\
\hline$\cdot . \Lambda \varepsilon$ & Y & $\cdot . \Lambda \varepsilon$ & $Y$ & $\therefore 9$ & $Y$ & $\cdot \wedge \varepsilon$ & $Y$ & $\cdot . \wedge \varepsilon$ & $r$ \\
\hline .991 & $\Gamma$ & .91 & $\Gamma$ & .91 & $r$ & .119 & $\Gamma$ & $\because \Lambda V$ & $r$ \\
\hline .94 & $\varepsilon$ & $\cdot . \Lambda V$ & $\xi$ &.$\wedge \mathrm{V}$ & $\xi$ & .91 & $\varepsilon$ & .119 & $\varepsilon$ \\
\hline.$\wedge 0$ & 0 & $\cdot . \Lambda r$ & 0 & $\cdot . \wedge \wedge$ & 0 &.$\wedge 7$ & 0 & .99 & 0 \\
\hline. .17 & 7 & $\cdot . \wedge \wedge$ & 7 & .99 & 7 & .91 & 7 &. .19 & 7 \\
\hline$\cdot . \wedge \mathrm{V}$ & $\mathrm{V}$ & $\cdot .10$ & $\mathrm{~V}$ &. .19 & $\mathrm{~V}$ & $\cdot \wedge \varepsilon$ & $\mathrm{V}$ & .99 & $\mathrm{~V}$ \\
\hline .99 & $\Lambda$ & .99 & $\Lambda$ & .91 & $\Lambda$ & $\because \Lambda \Lambda$ & $\Lambda$ &.$\wedge 0$ & $\Lambda$ \\
\hline .199 & 9 &. .19 & 9 & $\cdot \Lambda \varepsilon$ & 9 &.$\wedge 7$ & 9 & .91 & 9 \\
\hline$\cdot \wedge \wedge$ & 1. & .91 & 1. & $\cdot .19$ & 1. & .9. & 1. & $\cdot . \wedge V$ & 1. \\
\hline
\end{tabular}

يوضح جدول (V) وجود ارتباط ذو دلالة إحصائية بين التطبيق واعادة التطبيق لاستمارة استبيان الجينات التتظيمية وعلاقتها بالقدرات الابتكارية لدى العاملين بالمؤسسات الرياضية ، حيث تراوح معامل الارتباط مابين (r^. • - - 9 . • ) وهى معاملات ارتباط ذو دلالة عالية مما يشير الى ثبات الاستبيان.

- حساب معامل الثبات بإستخدام معامل ألفا كرونباخ : 
إستخدم الباحث معامل ألفا كرونباخليبان معامل ثبات إستمارةالإستنيان ، والجدول (^)

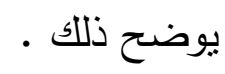

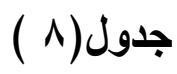

التجزئة النصفية ومعامل الفا لبيان معامل الثبات لاستمارة استبيان الجينات التنظيمية وعلاقتها

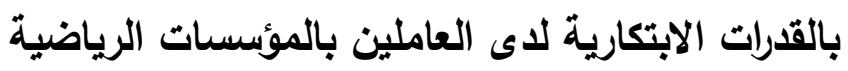

Y

\begin{tabular}{|c|c|c|c|c|}
\hline \multirow{2}{*}{$\begin{array}{c}\text { معامل الفا } \\
\begin{array}{c}\text { Cronbach's Alpha if } \\
\text { ItemDeleted }\end{array} \\
\end{array}$} & \multicolumn{2}{|c|}{ اختبار التجزئة النصفية } & \multirow[b]{2}{*}{ محاور المقياس } & \multirow[b]{2}{*}{ s } \\
\hline & جتمان & سبيرمان -براون & & \\
\hline 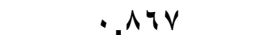 & $\cdot \wedge \leq r$ & $\because \wedge \circ \mu$ & وحدة اتخاذ القرار & 1 \\
\hline.$\wedge V Y$ & $\because \wedge ५$ & $\cdot \wedge \wedge \varepsilon$ & المحفزات & $r$ \\
\hline.$\wedge \vee 1$ & $\because \wedge 0 \leq$ & $\because \wedge M I$ & المعلومـات & $r$ \\
\hline$\cdot . \wedge$ ร & $\because \wedge 11$ & $\because \wedge \leq 7$ & الهيكل التنظيمى & $\varepsilon$ \\
\hline$\because A V Y$ & $\because$ • А५ & $\because$ •. & السلوك الابتكارى & 0 \\
\hline$\because \wedge \vee \vee$ & $\because \wedge \neg \wedge$ & $\because .190$ & الارجة الكلية & \\
\hline
\end{tabular}

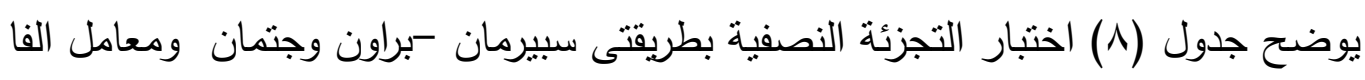

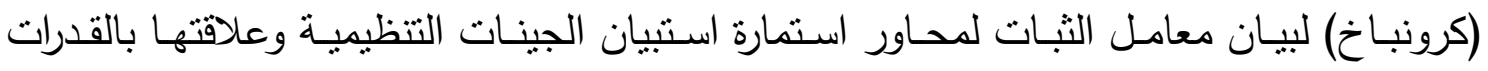

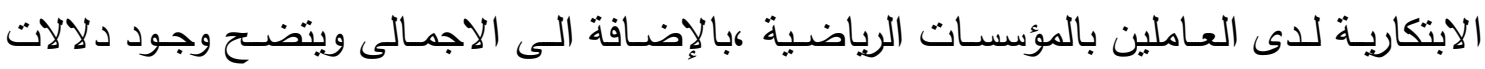
احصائية قوية تشير الى ثبات استمارة الاستبيان.

- الدراسات الإستطلاعية :

قام الباحث بإجراء الدراسة الإستطلاعية على مجموعة قوامها (Yo) فرداً ممثلة لمجتمع البحث

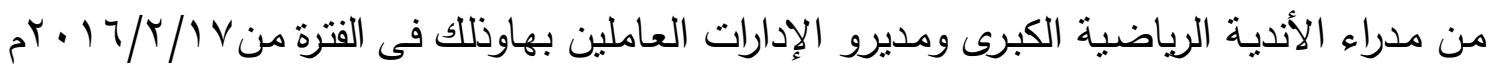

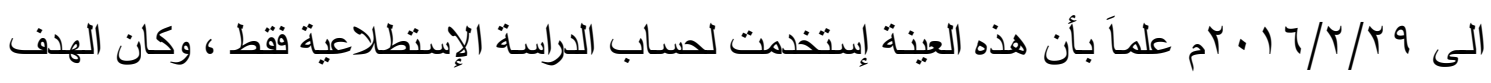

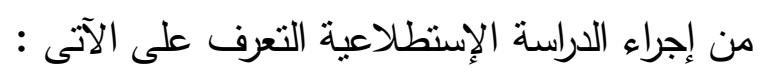
- مدى فهم عينة البحث للعبارات التى تتضمنها إستمارةالإستنيان. - التعرف على الصعوبات المحتمل ظهورها أثناء التطبيق للعمل على تلافيها ـ وقد أسفرت نتائج الدراسة الإسنطلاعية عما يلى :

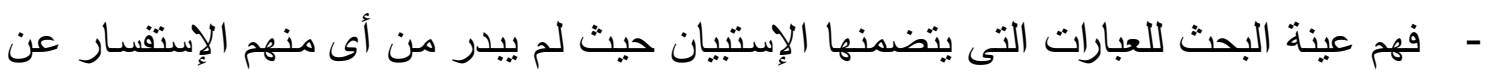
أى عبارات من عبارات الإسنتيان . 
- تـم التعـرف على زمـن إسـتمارة الإسـتبيان بحسـاب الـزمن الـذى إسـتغرقته عينــة الدراســة الإستطلاعية فى الإجابة على عبارات الإستبيان وكان يتراوح الزمن من 10 : . ب دقيقة .

\section{- تطبيق إستمارة الإستبيان :}

بعد التأكد من كافة الثروط العلمية والإدارية لإستمارة الإستبيان لجمع آراء العينة ، قام الباحث بتطبيق الإستمارة الإستبيان على مدراء الأندية الرياضية الكبرى ومديرو الإدارات العاملين

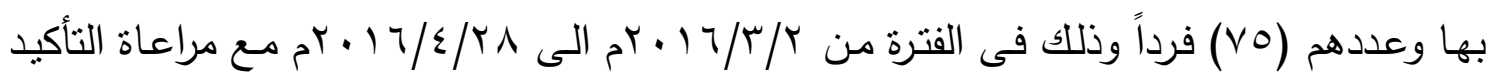

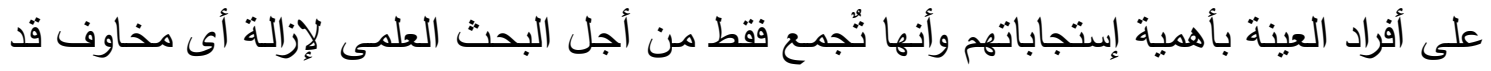
تقلل من تفاعلهم فى الإجابة على الإستبيان .

- المعالجات الإحصائية المستخدمة :

إستخدم الباحث المعالجات الإحصـائية الملائهـة لطبيعـة بيانات البحث وذلك من خـلال

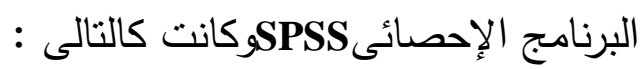
- المتوسط الحسابى -الإنحراف المعيـارى - معامل الاختلاف - معامـل الإرتبـاط - معامل الصدق ( صدق الإتساق الداخلى ) - معامل الثبات ( التطبيق - إعادة التطبيق Retest ( Test الثبات (جتمـان ) - النسبة المئويـة - الوزن النسبى - الأهمية النسبية - مصفوفة الارتباط

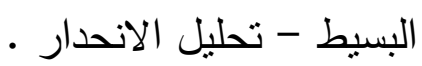


عرض النتائج ومناقشتها :

\section{جدول (9)}

تحليل فقرات المحور الاول الخاص بوحدة اتخاذ القرار

\begin{tabular}{|c|c|c|c|c|c|}
\hline الأهمية|لنسبية & معامل الاختلاف & الانحراف المعيارى & المتوسط الحسابى & 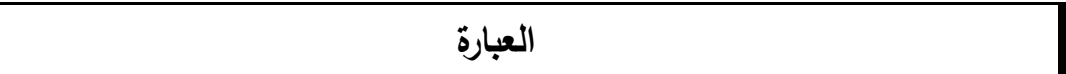 & م \\
\hline $99 . \vee \vee \wedge$ & $r r_{0} 0 \leq 0$ &. .711 & $r .9 r$ & أنثارك فى صنع واتخاذ القرارات المهة أو الاستراتيجية. & 1 \\
\hline$\neg \wedge . \wedge \wedge 9$ & rr.⿲丿 & $\cdot .7 \wedge \varepsilon$ & r.. TV & أهتم بالآراء المقدمة لى من كافة الاطراف عند اتخاذ القرار. & r \\
\hline$\neg \wedge . \wedge \wedge 9$ & rr.l11 & $\cdot .7 \wedge \varepsilon$ & r.. TV & التقدير الذى أحصل علية فى تقرير الكفاءة هو الذى أستحقه بالفعل. & $r$ \\
\hline$\neg \wedge . \wedge \wedge q$ & r.I1 & $. .71 \leq$ & $r . .7 V$ & تقوم إدارة النادى على تتجيع العاملين على التجديد والابتكار . & $\varepsilon$ \\
\hline V. rrr & Pl.v7q &. .799 & $r .1 \cdot v$ & أنثعر بعدالة فى المعاملة بسبب تطبيق سياسة الثواب والعقاب. & $\stackrel{0}{0}$ \\
\hline R. Rrr & trater & $\cdot v \cdot q$ & r.1.v & تقوم ثقافة النادى على الاهتمام بمراحل العمل مع التركيز على التفاصيل والنتائج. & 7 \\
\hline$\curlyvee \wedge . \wedge \wedge q$ & $r r .111$ &. $.7 \wedge \varepsilon$ & r. $.4 \mathrm{~V}$ & توفر الإدارة العليا للنادى بيئة تتافسية ابتكارية بين الأفراد العاملين به. & $v$ \\
\hline$\curlyvee \wedge . \wedge \wedge q$ & rr.111 & $. .7 \wedge \leq$ & r.. TV & أسمح لزملائي بالمشاركة فى وضع خطط وأهداف العمل. & $\wedge$ \\
\hline$\neg \wedge . \wedge \wedge 9$ & rr. I1 & $\cdot .71 \varepsilon$ & r.P TV & اتخذ قرارتى مراعيا قدرات العاملين وامتلاكهم المعرفة اللازمة لتنفيذ القرارات. & 9 \\
\hline$\because \imath_{.} \cdot \ldots$ & 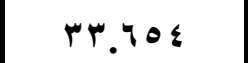 &..$\wedge \vee$ & r.. $\varepsilon$. & ايقوم النادى الذى اعمل به على احترام وتقدير الأفراد العاملين به. & 1. \\
\hline
\end{tabular}


يوضح جدول (9) تحليل عبارات المحور الاول الخاص بوحدة اتخاذ القرار للى العاملين

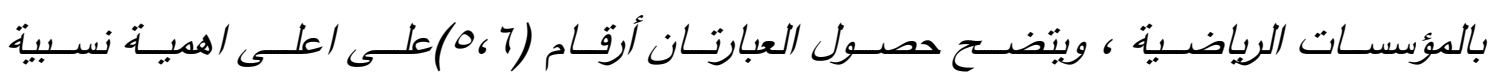

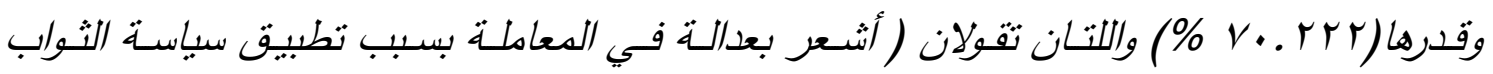
والعقاب ) و (تقوم ثقافة النادى على الاهتمام بمرحل العدل مع التركيز على التفاصيل والنتائج

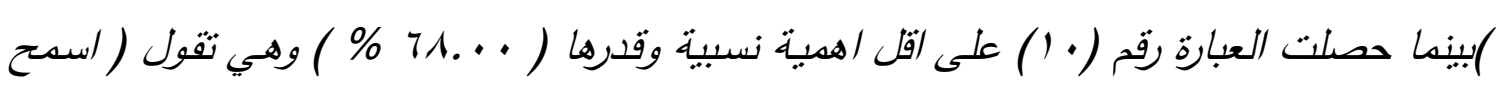
لزمالئي بالمشاركة في وضع خطط وأهداف العهل ). وبرى الباحث أن اتفاق العينة على أن هناك عدالة في الدعاملة يُعبر عن الثقة والمصد/قية تجاه الإدارة ، وهو ما بنعكس إيجابيًا على المرؤوسين وقناعتهم بأن اتخاذ القرار بتم بطريقة حكبية

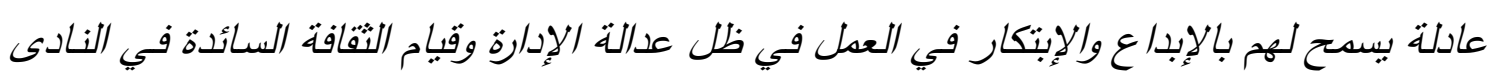
على الاهتمام بمراحل العدل والاهتدام بكافة التفاصيل الدقيقة لكل مرحلة وتقوبم النتائج النهائية

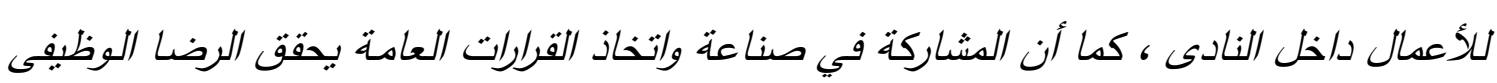

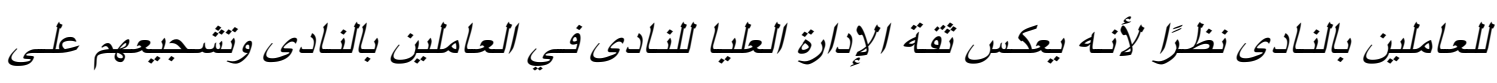

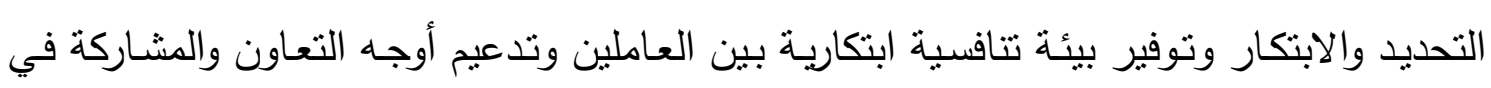
وضع وتتفيذ خطط وأهداف العمل داخل النادى مما يساعد على تحقيق الوحدة في اتخاذ القرارات . وهذا ما يتفق مع نتائج بعض الدراسات المرتبطة مثل دراسة ( محمد عبد التواب البكرى

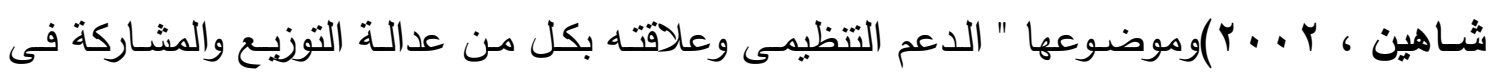
اتخاذ القرارات والكفاءة الاجتماعية " ، والتى توصلت إلى وجود علاقة معنوية موجبة بين عدالة الإجراءات ، كأحد عناصر الدعم التتظيمى ، والقدرات الابتكارية للعاملين ، وكذللك دراسة ( مايكل

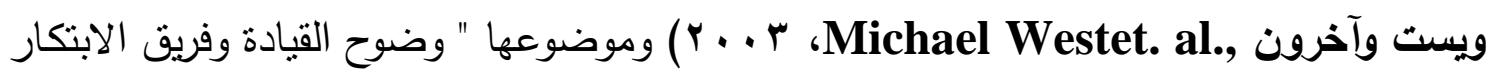
فى مجال الرعايـة الصحية " ، والتى توصلت إلى أن عدم معرفة من لـه الحق فى اتخاذ القرار يؤدى إلى نقص إبداعات العاملين داخل المنظمة ، ودراسة (ليو برونو Leo F.C. Bruno،

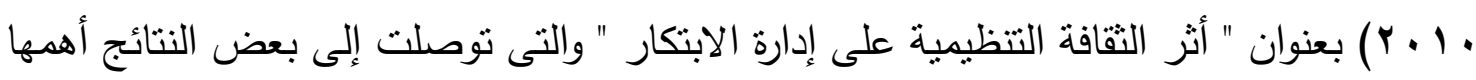
أن ثقافة المنظمة يكون لها دور كبير فى تتمية القدرات الإبداعية فى المنظمة ،ودراسة (ستيفيشيير

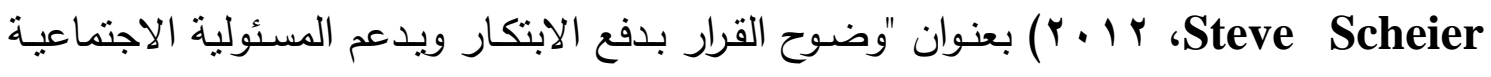


وتحسين القيمة على المدى الطويل " ، والتى توصلت إلى بعض النتائج منها أن الغموض فى عملية اتخاذ القرار يؤثر بشكل كبير على كفاءة العمليات التى تتم فى المنظمة وكذلك يؤدى إلى

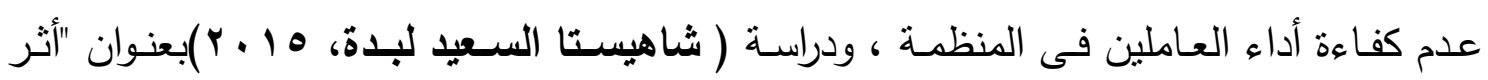
الجينات التتظيمية علي قدرات المرؤوسين الابتكارية " والتى توصلت إلى بعض النتائج منها أن ثقافة المنظمة هي أكثر المتغيرات التي تعكس حقوق إنخاذ القرار من حيث التأثير علي قدرات المرؤوسين الإبتكاريـة وعدم معنويـة تأثثر المشـاركة فى اتخـاذ القـرار على القدرات الابتكاريـة

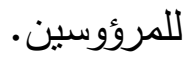




\section{جدول ( · )}

تحليل فقرات المحور الثانى الخاص بالمحفزات

\begin{tabular}{|c|c|c|c|c|c|}
\hline الأهمية|لنسبية & 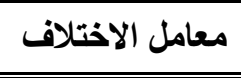 & الانحراف المعيارى & المتوسط الحسابى & 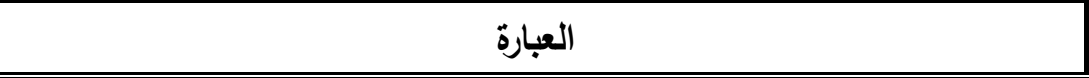 & b \\
\hline $99 . \vee \vee \wedge$ & r.. $0 \leq 0$ &. .711 & r..9r & الراتب الذى أنقاضاه يتتاسب مع المجهود الذى ابذله فى العمل & 1 \\
\hline 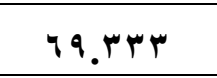 & rr.rov &. $.7 V r$ & r..ı. & مستويات الأجور تتتاسب مع الأوضاع الاقتصادية الحالية. & r \\
\hline$v 0.007$ & rE.YVY & $\therefore$. v V & r.rTV & يرتفع ادائى الوظيفى وقدرتى على الابتكار كلما شعرت بالأمان الوظيفى. & $r$ \\
\hline$\neg \wedge . \wedge \wedge 9$ & rr.l11 & $\because .71 \leq$ & $r . \cdot 4 \mathrm{r}$ & ليرتبط الراتب الذى أحصل عليه بسنوات الخبرة . & $\varepsilon$ \\
\hline$\neg \wedge . \wedge \wedge 9$ & r r..111 &. $.71 \varepsilon$ & r.PTV & رغبتى فى زيادة راتبى تدفعنى للحصول على دراسات متقدمة فى عملى . & 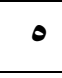 \\
\hline$\neg \wedge . \wedge \wedge 9$ & rr.l11 &. $.71 \varepsilon$ & $r . \cdot t r$ & أبذل قصارى جهدى فى العمل لتحقيق المزيد من المكافأت والحوافز المادية. & 9 \\
\hline$\Upsilon \wedge . \leq \leqslant \leq$ & $r$ r.q. A &. $.7 \vee 7$ & r..or & أشعر بعدالة الادارة فى توزيع المكافأت على العاملين بالإدارةالتى اعمل بها. & V \\
\hline $7 \leq . \leq \leqslant \leq$ & ro.s.r & $.71 \leq$ & $1.9 \mu r$ & العمل فى وسط جماعة صغيره الحجم يزيد من الارتباط بالأحاسيس والأفكار بيننا . & $\wedge$ \\
\hline$\curlyvee \wedge . \wedge \wedge 9$ & rr.111 & $. .71 \leq$ & r.P. TV & اجد دعم وتتجيع من الزملاء عندما أعرض عليهم افكارى الخاصة بزيادة الحوافز . & 9 \\
\hline$\Upsilon \wedge . \wedge \wedge 9$ & r..111 &. $.71 \varepsilon$ & $r . \cdot T V$ & ليرتبط الراتب الذى أحصل عليه بمؤهلى العلمى . & 1. \\
\hline
\end{tabular}


يوضـح جدول ( • ( ) تحليل عبارات الدحور الثانى الخاص بـالدحفزات للى العاملين

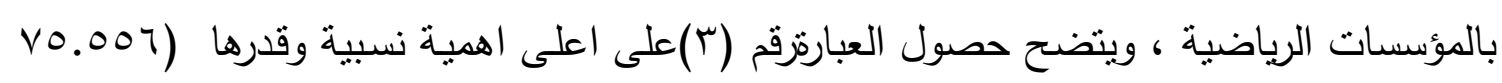
\%) وهي نقول (يرتفع أدائي الوظيفي وقدرتي علي الإبتكار كلما شعرت بالامان الوظيفي) بينما حصلت العبارة رقم (^) وهي تقول (العمل في وسط جماعـة صغيرة الحجم يزيد من الارتباط

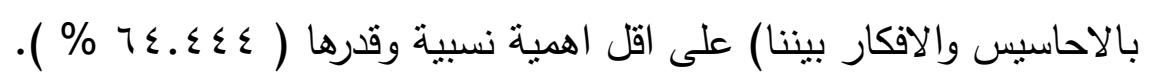

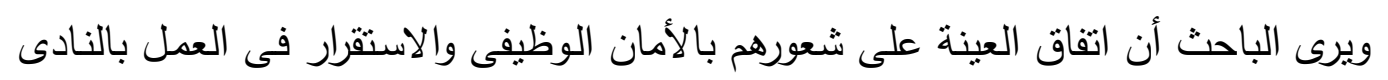

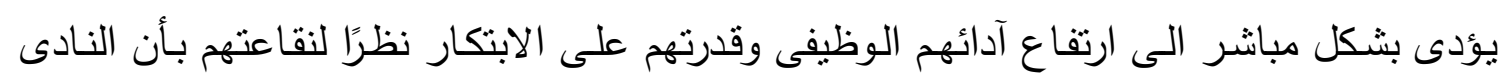

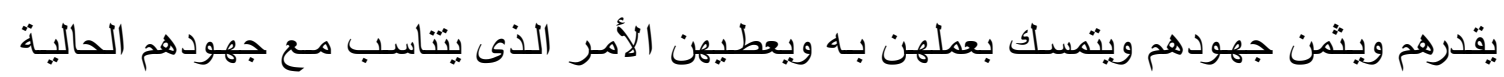
وخبراتهم السابقة ويشجعهم على تتمية مهاراتهم التدريبية والثخصية عن طريق الدراسات العلمية

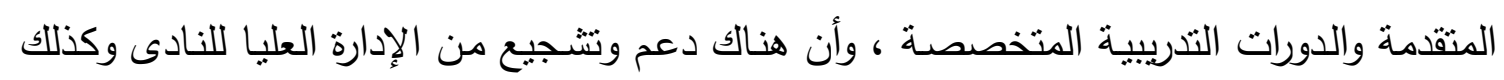
زملاء العمل عند عرض أية مقترحات تنساهم في تحقيق الرضـا الوظيفى وتحقيق دوافع إيجابية وانية للعاملين بالنادى .

Ahmed ويتفق هذا مع نتائج بعض الدراسات المرنبطة مثل دراسة (أحمد قمر وآخرون

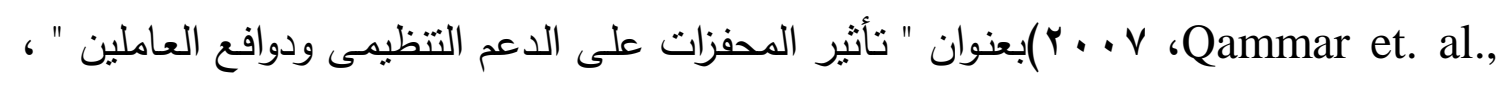
وقد توصلت الدراسة إلى بعض النتائج منها أنه هناك تأثير معنوى قوى بين المحفزات والقدرات

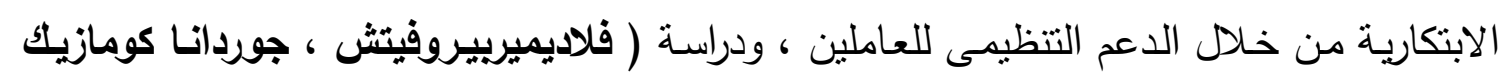

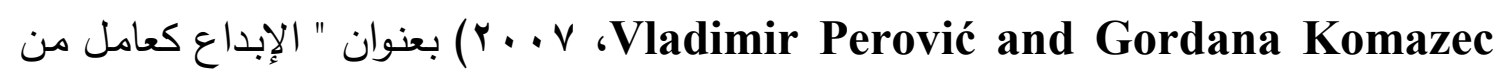
القدرة التتافسية فى السوق الدولية " ، والتى توصلت إلى أن العاملين يتأثرون بالحوافز المعنوية

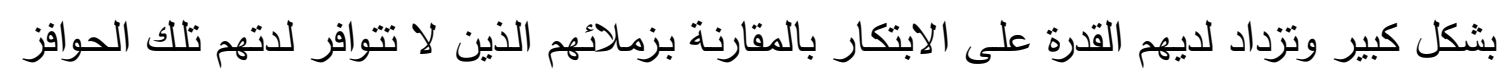

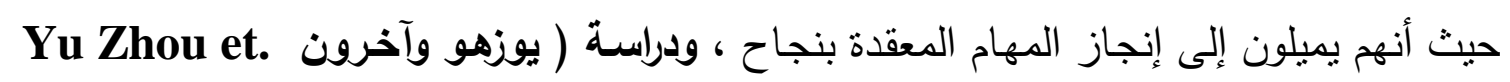
ral.,

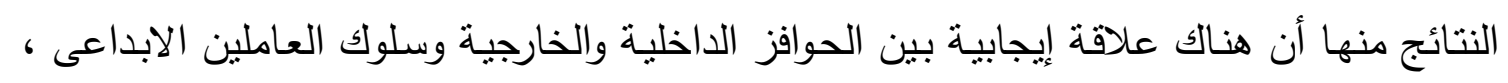

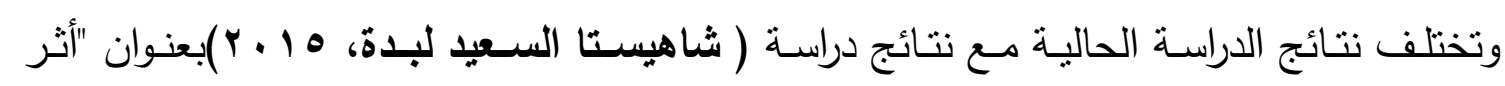
الجينات التتظيمية علي قدرات المرؤسين الابتكارية " والتى توصلت إلى بعض النتائج منهاعدم

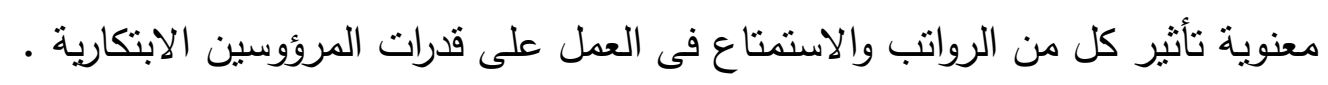




\section{جدول ( )}

تحليل فقرات المحور الثالث الخاص بالمعومات

\begin{tabular}{|c|c|c|c|c|c|}
\hline الأهمية|لنسبية & معامل الاختلاف & الانحراف المعيارى & المتوسط الحسابى & العبارة & r \\
\hline$v v_{.} \ldots$ & $r \cdot . r 10$ &. .719 & r.r^. & |لا أجد صعوبة فى الحصول على المعلومات اللازمة للإنجاز · & 1 \\
\hline$\vee ५ . \wedge \wedge 9$ & ro.7Vi & $.09 r$ & $r . r \cdot v$ & |أعتمد بشكل كبير على المعلومات المتوفرة لتتفيذ مهام عملى. & r \\
\hline$v v_{.} \ldots$ & $r \cdot . r 10$ &. $.7 \wedge 9$ & r.r^. & ليتأثر أدائى الوظيفى بمدى نوافر المعلومات المتعلقة بتلك الوظيفة & $r$ \\
\hline$v r_{.} \ldots$ & r.. $1 \Lambda$ & $.7 \vee 9$ & r.17. & توافر المعلومات الوظيفية يدفعنى لبذل مزيد من الجهد لتحقيق أهداف النادى. & $\varepsilon$ \\
\hline VE. rrr & r.. 119 & $\cdot v \cdot q$ & r.rrV & |المعلومات التى أحصل عليها تتسم بالدقة والثشمول والموضوعية. & $\bullet$ \\
\hline Vr.rrr & r.v. &. $.79 \mathrm{~V}$ & r.r... & أحكم على مدى ملائمة المعلومة من خلال قدرتها على تحقيق الهدف المنشود. & 9 \\
\hline Vr. $\varepsilon \leqslant \varepsilon$ & $r \varepsilon .1 \leq r$ & $\cdot V \leqslant r$ & r.lvr & إيوجد نظام متكامل للمعلومات بالنادى الذى أعمل به & V \\
\hline VY. $\varepsilon \leq \varepsilon$ & rY.\&Y &.$\vee \cdot \bullet$ & r.lvr & لجودة المعلومات مرتبطة بتوقيت الحصول عليها. & $\wedge$ \\
\hline$V Y . \leqslant \leq \leqslant$ & r. r. Y $\leqslant$ &.$v \cdot \bullet$ & r.lvr & |الموارد المالية المتاحة بالنادى هي المحدد الأساسى للحصول عالى المعلومات. & 9 \\
\hline$\vee{ }^{\prime} . \ldots$ & $r \cdot . r 10$ &. $.7 \wedge 9$ & r.r^. & |أتحقق من صحة المعلومات المقدمة لى باستمرار . & 1. \\
\hline
\end{tabular}


يوضـح جدول (1') تحليل عبارات المحور الثالث الخـاص بالمعلومـات لدى العـاملين

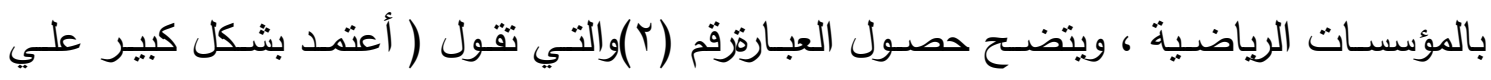

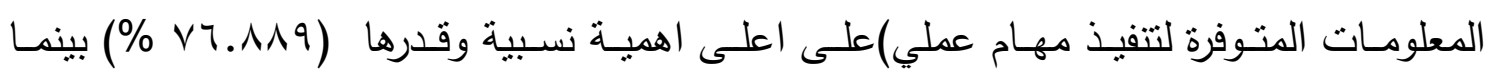
حصلت العبارة رقم (ع) والتي تقول (توافر المعلومات الوظيفية يدفعني لبذل مزيدا من الجهدلتحقبق

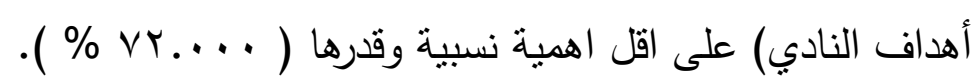
يرى الباحث أن اتفاق معظم آراء العينة على اعتمادهم في تتفيذ مهام عملهم بشكل كبير

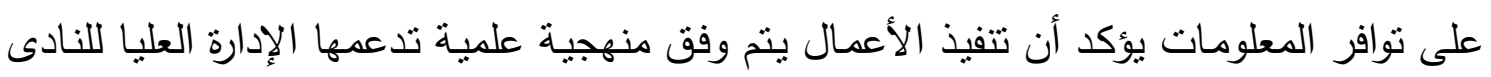
حيث ان نوافر المعلومات بصورة جيدة من الطبيعى أن ينتج عنه تتفيذ الأعمال بكفاءة وفاعلية وفقًا للأهداف المحددة نظرًا لسهولة الحصول على المعلومات التي تتميز بالدقة والثمول والموضوعية في ظل وجود نظام متكامل للمعلومات بالنادى يتيح الحصول على المعلومات في الوقت المطلوبة بهربة

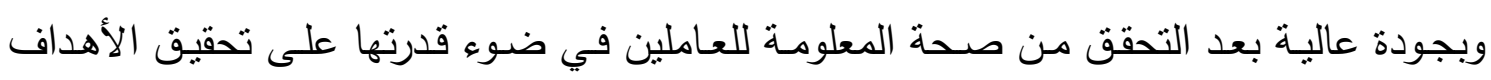
المنشودة للنادى .

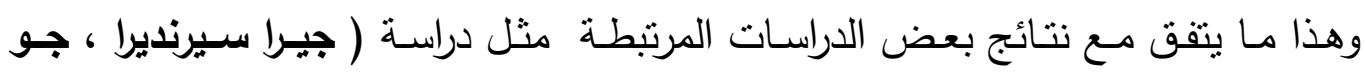

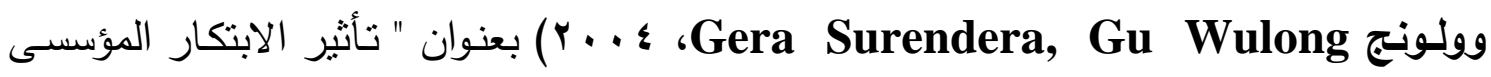

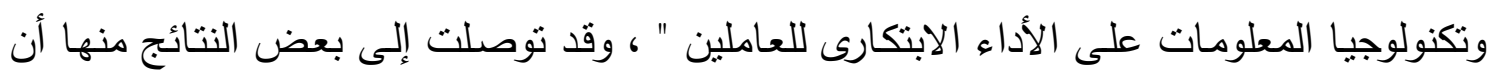

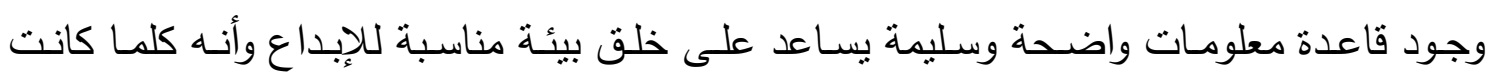

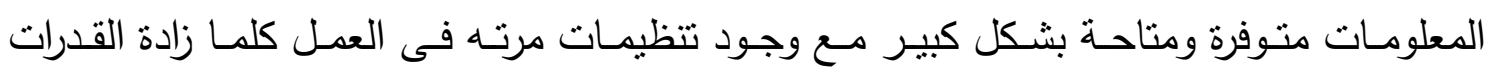

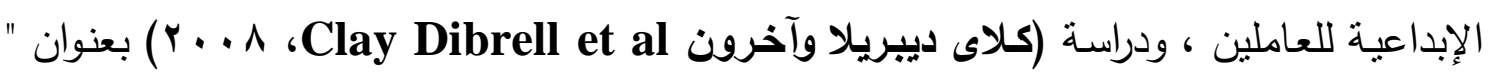
تعزير الابتكار من خلال تكنولوجيا المعلومات فى الثركات الصغيرة والمتوسطة " ، حيث بينت

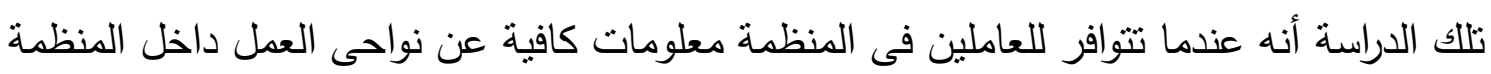

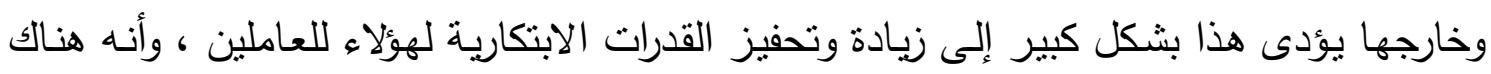

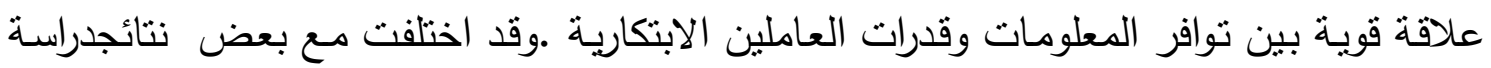

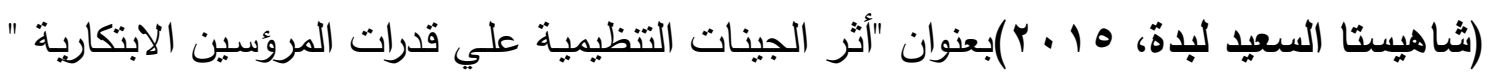

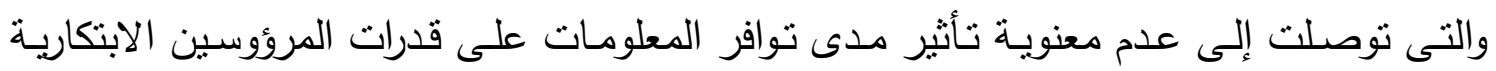

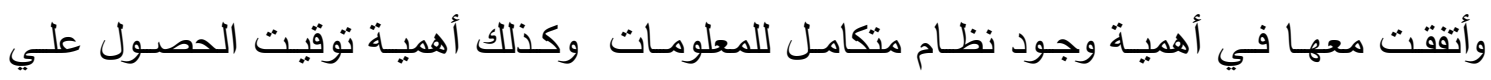
المعلومة. 


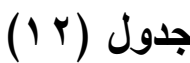

تحليل فقرات المحور الزرايع الخاص بالهيكل التظيمى

\begin{tabular}{|c|c|c|c|c|c|}
\hline الأهمية|النسبية & 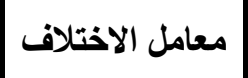 & الانحراف المعيارى & | المتوسط الحسابى & 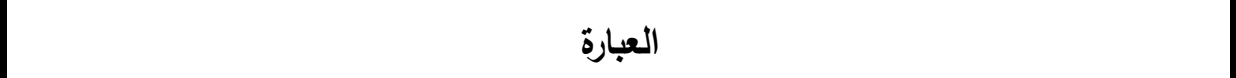 & r \\
\hline T9.rur & rr.r.q &. .794 & $r_{.} \cdot \wedge$. & الهيكل التنظيمى للنادى يحدد السلطات والمسئوليات بصورة واضحة . & 1 \\
\hline$\neg \wedge . \wedge \wedge 9$ & r..l11 & $\cdot .71 \leq$ & r.PV & الهيكل التنظيمى للنادى يوفر تتظيماً جيداً للمستويات الإدارية . & r \\
\hline$\neg \wedge . \wedge \wedge 9$ & rr. 11 & $. .71 \leqslant$ & r.PV & الهيكل التنظيمى للنادى يوفر القواعد والوسائل اللازمة لتقييم أداء العاملين . & r \\
\hline $90 . r \mu r$ & ro. ru &..$\top \wedge \mathrm{v}$ & 1.99. & يحدد الهيكل التنظيمى عدد المستويات الإدارية ونطاق الإثراف الخاص بها ـ. & $\varepsilon$ \\
\hline 94.111 & $\mu 0 . r \leqslant q$ & .779 & $1 . \wedge 94$ & النادى يوفر التوصيف الوظيفى للوظائف مما يساعد على اختبار الوظيفة المناسبة الفرد . & $\bullet$ \\
\hline$\neg \wedge . \wedge \wedge q$ & $r r .111$ &. $.7 \wedge \varepsilon$ & r. $\cdot 7 V$ & الإدارة العليا للنادى تعمل على تطوير ومرونة هيكلها التظظيمى للاستجابة لأى متغيرات جديدة. & 7 \\
\hline$\neg \wedge . \wedge \wedge 9$ & rr.111 &. $.71 \varepsilon$ & r.PTV & يحقق الهيكل التنظيمى للنادى معرفة جميع العاملين للقوانين واللوائح المنظمة للعمل . & $\mathrm{v}$ \\
\hline$\curlyvee \wedge . \wedge \wedge q$ & rr.111 & $. .7 \wedge \leq$ & r.PV & الهيكل التظيمى للنادى يتتاسب مع حجم النادى وشعبيته. & $\wedge$ \\
\hline $99 . r m$ & rr.rov & $\because \mathrm{TVH}$ & $r . \wedge$. & الهيكل التنظيمى بهنم و يميز بين النشاطات المهمة والأقل أهمية. & 9 \\
\hline$\neg \wedge . .$. & rr.tos &.$\neg \wedge \vee$ & r.. $\varepsilon$. & الهيكل التنظيمى مصمم بحيث يضمن توافر وسائل رقابية للإدارة العليا للنادى . & 1. \\
\hline
\end{tabular}


يوضح جدول (r ( ) تحليل عبارات المحور الرابع الخاص بالهيكل التظيمى لدى العاملين بالمؤسسـات الرياضـية ، ويتضـح حصـول العبـارة رقـم ( (1)على اعلى اهيــة نسبية وقـرها

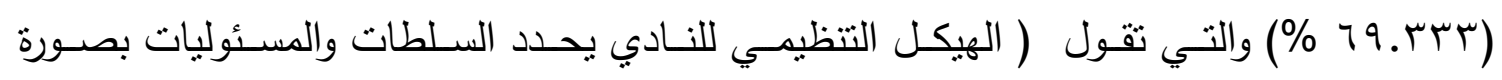
واضحة) بينما حصلت العبارة رقم (0 ) والتي تقول ( النادي يوفر التوصيف الوظيفي للوظائف مما

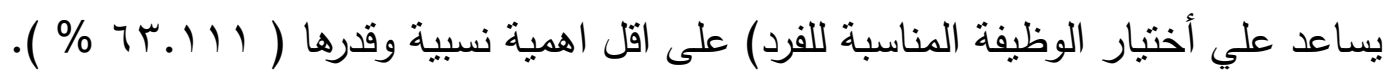
يرى الباحثة أن اتفاق عينة البحث على أن تجديد السلطات والمسئوليات بصورة واضحة داخل الهيكل التنظيمى يُساهم في فهم وإدراك كافة العاملين بالنادى لطبيعة وظائفهم مـع وجود التوصيف الوظيفى لهذه الوظائف وبيان ما هي الأهداف المطلوب منهم إنجازها مع منحهم كافة

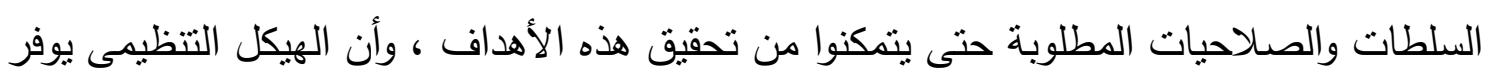
قواعد ووسائل مناسبة لتقيمي أداء العاملين مما في التعرف على نواحى القوة وتدعيمها ونواحى ماهى القصور في الأداء والعمل على علاجها والتغلب عليها من خلال التدريب أو أية وسائل مناسبة ، في ظل وجود هيكل تتظيمى مرن يستجيب لأية متغيرات جديدة وتوافر معرفة وفهم جيد لقوانين العمل واللوائح المنظمة له داخل النادى يترتب عليها وضع الثخص المناسب في المكان المناسب مـع ضرورة تكوين الهيكل التنظيمى للنادى بما يتتاسب مـع حجم النادى وشعبيته بحيث تغطى المستويات الإدارية المختلفة كافة القطاعات التي يتعامل معها أعضاء النادى أو الجهات الخارجية في البيئة المحبطة بالنادى .

وهذا ما يتفق مع نتائج بعض الدراسات المرتبطة مثل دراسـة (أندريافاونا ، مـاريو بيانتا Andrea Vaona, Mario Pianta الأوربية" ، وقد توصلت تلك الدراسة إلى أن المنظمات كبيرة الحجم تتضح بها القدرات الإبداعية

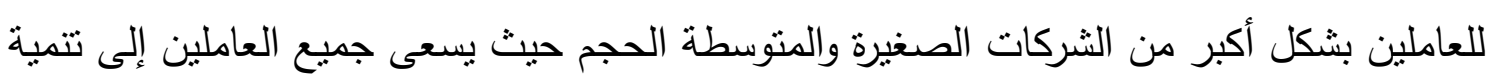
Bordia مهاراتهم وقدراتهم وذللك لتحقيق ميزة تتافسية عن بقية زملائهم ، ودراسة (بورديا وآخرون

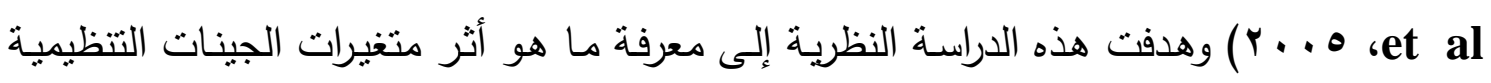
مجمعة وهم (حقوق اتخاذ القرار ، المحفزات ، جودة المعلومات ، الهيكل التنظيسى) على قدرات

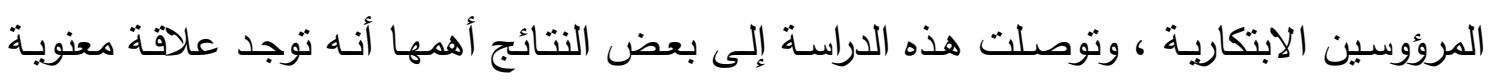

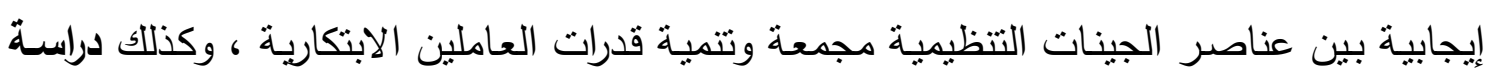




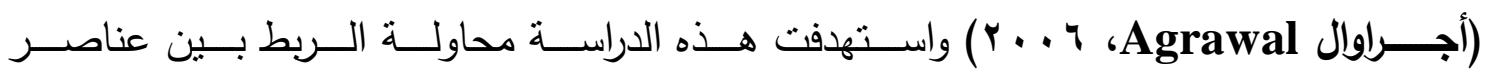
Organizational DNA المتغيرات التى يتكون منها مفهوم الـOrganizational DNA وتأثنير هذا المفهوم على تتميـة المهارات الإبداعية لهؤلاء المديرين وتوصلت هذه الدراسة إلى بعض النتائج أههها أن حقوق اتخاذ

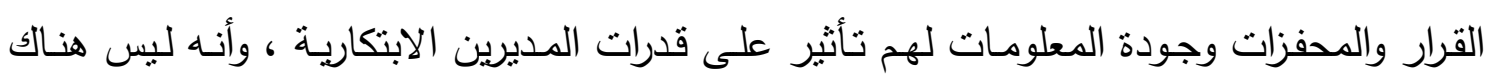
هيكل تتظيمى محدد ومعروف يمكن استخدامه فى قياس قدرات المرؤوسين الابتكارية بشكل عام ، وإنما يختلف الهيكل التتظيمى من شركة لأخرى فى تأثثره على تتمية القدرات الابتكارية للمدريين ، وهناك دراسة ( عادل عبد المنعم المسدى ، 9 . . Y) بعنوان " نموذج مقترح للعلاقة بين الجينات

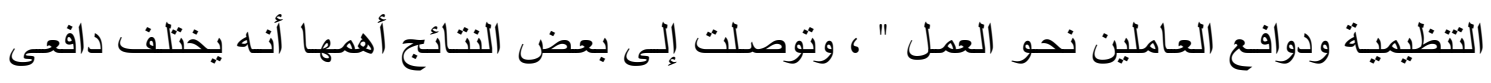
الإنجاز والقوة إختلافاً معنوياً تبعاً للاختلاف فى حقوق اتخـاذ القرار ، وأنه بوجد تأثنير لثكل وطبيعة الهيكل التتظيمى على دافعى الانتماء والقوة ، ودراسة (ثاهيستا السعيد لبدة ، 10 ـ ب) بعنوان " أثر الجينـات التتظيمية على قدرات المرؤوسين الابتكاريـة " دراسـة تطبيقه على البنوك

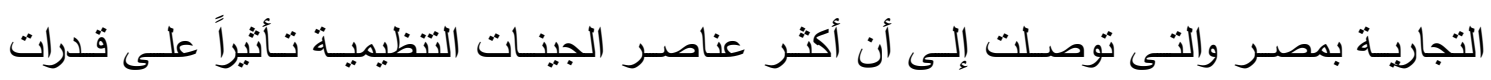
المرؤوسين الابتكارية هو الهيكل التتظيميليه المحفزات ثم جودة المعلومات. 


\section{جدول ( ب آ )}

تحليل فقرات المحور الخامس الخاص بالسلوك الابتكارى

\begin{tabular}{|c|c|c|c|c|c|}
\hline الأهمية|النسبية & 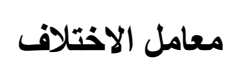 & الاتحراف المعيارى & المتوسط الحسابى & 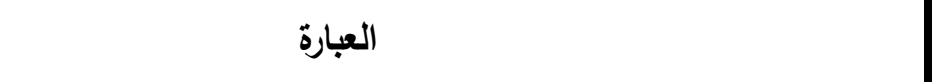 & 5 \\
\hline$\curlyvee \wedge . \wedge \wedge 9$ & rr.111 & $\because .71 \leq$ & $r . \cdot 7 V$ & | افكر دائما قبل القيام بأى عمل . & 1 \\
\hline$\Im \wedge . \leqslant \leqslant \leqslant$ & 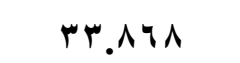 &. .790 & r.or & |أبتعد دائما عن الأعمال السهلة أو البسيطة . & r \\
\hline TM.ru & rr.rov &. $.7 \vee r$ & $r . \wedge$. & للدى القدرة على التحليل والربط بين الموضوعات المرتبطة بالعمل . & $r$ \\
\hline $79 . \vee \vee \wedge$ & $r r . \varepsilon \vee q$ & $\cdot v \cdot 1$ & r..qr & |أتقبل انتقادات الآخرين بصدر رحب . & $\varepsilon$ \\
\hline$\curlyvee \wedge . \wedge \wedge 9$ & rr.j1 &. $.7 \wedge \varepsilon$ & $r_{.} \cdot T V$ & |اسعى باستمرار الى تقديم الجديد فى عملى . & $\bullet$ \\
\hline$\neg \wedge . \wedge \wedge q$ & $r r .111$ &. $.7 \wedge \varepsilon$ & r.PV & |أقسم مهامى فى العمل الى أجزاء صغيرة وأدرس كل جزئية على حدة . & 1 \\
\hline$V \cdot .77 V$ & r. & $\because .7 \vee V$ & r.lr. & أرغب فى الالتحاق ببرامج تدريبية فى تخصصى . & v \\
\hline $99 . r \mu r$ & rr.r.q &. $.79 \mu$ & r.. $\wedge$. & |أسعى لتحقيق التميز للنادى الذى أعمل به عن طريق الابتكار. & $\wedge$ \\
\hline$\curlyvee \wedge . \wedge \wedge 9$ & r..l11 &. $.7 \wedge \varepsilon$ & $r_{.} \cdot T V$ & لا احب الاعمال المتكررة أو الروتينية . & 9 \\
\hline$\curlyvee \wedge . \wedge \wedge 9$ & r..11 &. $.71 \varepsilon$ & r.PV & |لدى خطط مسبقة لمواجهة الأزمات قبل حدوثها . & 1. \\
\hline
\end{tabular}


يوضـح جدول (r () تحليل عبارات الحسور الخـامس الخـاص بالعناصر التى تعكس قدراتالعاملين الابتكارية بالمؤسسات الرياضية ، ويتضح حصول العبارة رقم (V)على اعلى اهمية

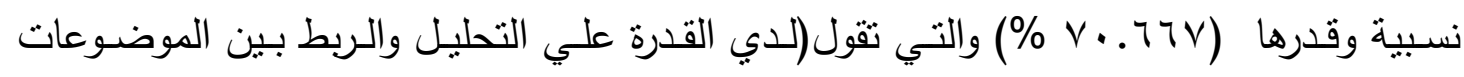

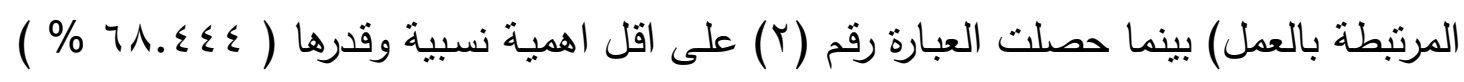
وهي تقول (أبتعد دائما عن الاعمال السهلة أو البسيطة ) .

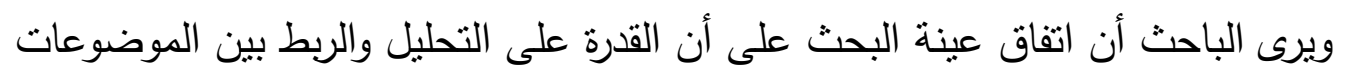

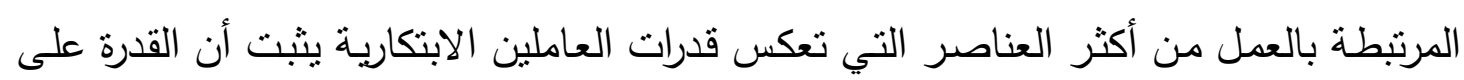
استخدام الأسلوب العلمى في التعامل مـع جوانب العمل المختلفة من خـلال دراسـة مفرداتها وتحليلها والتعرف على أوجـه التثـابه والارتباط بين مجالات العمل بكفاءة وفاعلية ينتج عنهـ

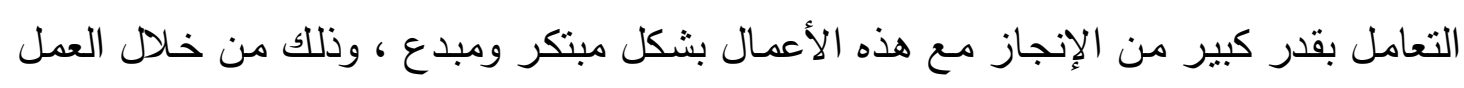
على تقدير الأفكار والمقترحات الجديدة في مجال العمل ووضع خطط مسبقة لمواجهة وإدارة الأزمات المتوقعة مما يساهم في تحقيق ميزة تتافسية متفردة للنادى ، كما أن الرغبة في الالتحاق

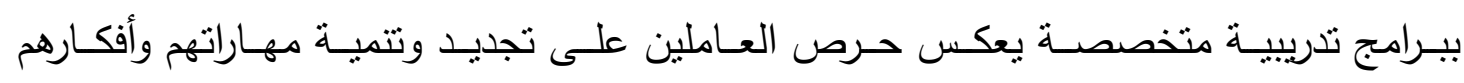
ومعلوماتهم المرتبطة بشكل مباشر بمجال عملهم مما يساعد على تتمية قدراتهم الابتكارية . وهذا ما ينفق مع نتائج بعض الدراسات المرتبطة مثل دراسة ودراسة ( بورديا وآخرون Bordia et al التتظيمية مجمعة وهم (حقوق اتخاذ القرار ، المحفزات ، جودة المعلومات ، الهيكل التتظيمى)

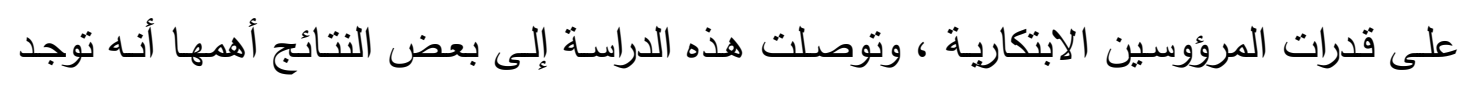
علاقة معنوية إيجابية بين عناصر الجينات التتظيمية مجمعة وتتمية قدرات العاملين الابتكارية و ولهوبين

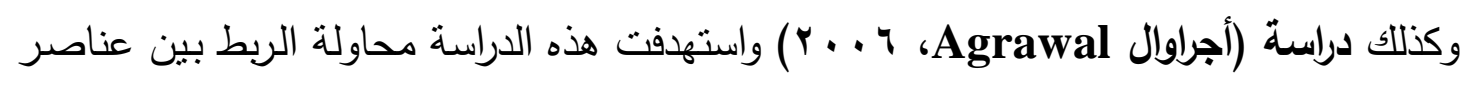
Organizational DNA

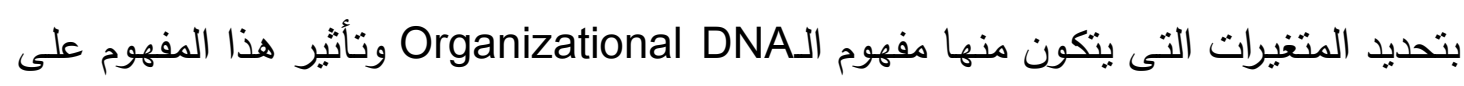

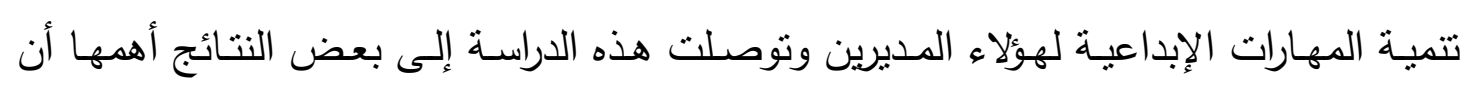

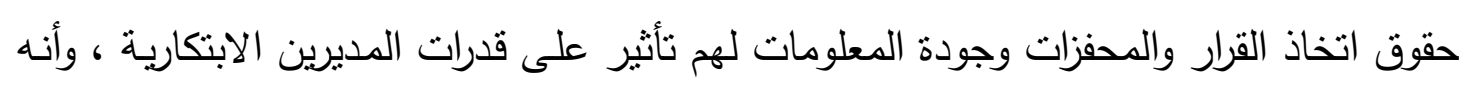
ليس هناك هيكل تتظيمى محدد ومعروف يمكن استخدامه فى قياس قدرات المرؤوسين الابتكارية بشكل عام ، وإنما يختلف الهيكل التتظيمى من شركة لأخرى فى تأثثره على تتميـة القدرات 
الابتكاريـة للمدريين و دراسـة (عـادل عبد المـنعم المســى ، 9 . . †) بعنوان " نموذج مقترح للعلاقة بين الجينات التتظيمية ودوافع العاملين نحو العمل " وتوصلت إلى بعض النتائج أهمها أنه يختلف دافعى الإنجاز والقوة إختلافاً معنوياً تبعاً للاختلاف فى حقوق اتخاذ القرار ، وأنه يوجد تأثثر لثكل وطبيعة الهيكل التنظيمى على دافعى الانتماء والقوة .

\section{جدول( 1 ( )}

مصفوفة الارتباط البسيط بين محاور استبيان الجينات التظظيمة -على السلوك الابتكارى الجينات التنظيمية لاى العاملين بالمؤسسات الرياضية

\begin{tabular}{|c|c|c|c|c|c|}
\hline الهيكل التنظيمى & المعلومات & المحفزات & حقوق اتخاذ القرار & المحاور & $p$ \\
\hline & & & & وحدة اتخاذ القرار & 1 \\
\hline & & & $\therefore .1 \% \Lambda$ & المحفزات & $r$ \\
\hline & & 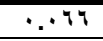 & $\because 11 \varepsilon$ & المعلومات & $r$ \\
\hline & $\therefore 10 \%$ &. $.14 \pi$ & $\because \because \leqslant \wedge$ & الهيكل التتظيمى & $\varepsilon$ \\
\hline$" \because . \vee \Upsilon \xi$ & $* \cdot . \wedge I V$ & $" \cdot . \wedge v \Psi$ & $" \because .940$ & السلوك الابتكارى & \\
\hline
\end{tabular}

يوضح جدول (ع () مصفوفة الارتباط البسيط بين محاور استنيان الجينات التنظيمية و السلوك

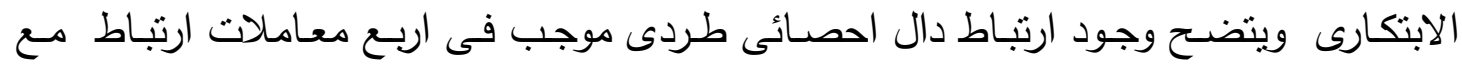

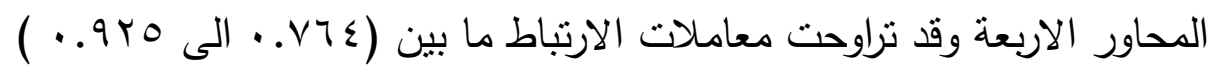

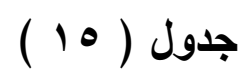

تحليل الانحدار لمحاورالجينات التظيمية -على السلوك الابتكارى

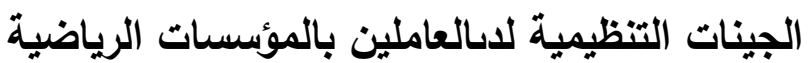

\begin{tabular}{|c|c|c|c|c|c|c|c|c|}
\hline $\begin{array}{c}\text { التفبير } \\
\text { R2 } \\
\text { Adjusted }\end{array}$ & \multicolumn{4}{|c|}{ معاملات الانحدار } & قيمة ف & الثقابت & المعيارى الخطا & المؤشرات المساهمة \\
\hline 01.7. & & & &.$\vee \vee 9 \varepsilon$ & $0 r \wedge .10 r$ &. .741 &. $.11 \mathrm{~V}$ & المعلومات \\
\hline VI. E. & & &. $.0 \mathrm{VV}$ & $\cdot .7 \leq 1$ & $\varepsilon \varepsilon 7.1 Y Y$ & $\cdot . \wedge 9 r$ &. .101 & المعلومات +المحفزات \\
\hline$\Lambda \leqslant .0$ & &..$\mu 1 \Lambda$ & $\because .0 \leqslant r$ &..$O T H$ & $M \leq . \vee 70$ & .807 & $\cdot .1 \leqslant r$ & المعلومات +المحفزات التخاذ القرار \\
\hline $94 . r$. & $\cdot$ ror &.$r \wedge q$ & $\cdot . \leqslant V r$ & $\cdot .291$ & $r V 0 . \varepsilon 7 r$ & $\cdot . \wedge 9 \wedge$ & • & 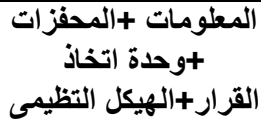 \\
\hline
\end{tabular}

يوضح جدول (10) ملخص لنموذج الانحدار المتعدد بطريقة Stepwise ويعرض الجدول

مربع معامل الارتباط المتعدد او معامل التحديد فى الاربعة حالات ويتضح ان الحالة الاولى قد حددت متغير المعلومات كأكبر وافضل متغير مساهم تاثيرعلى السلوك الابتكارى لاى العاملين بالمؤسسات

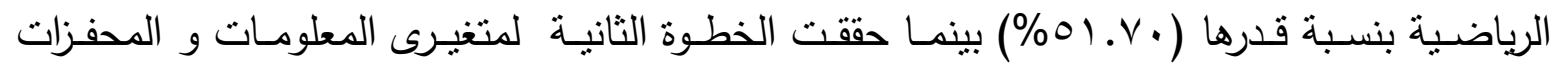




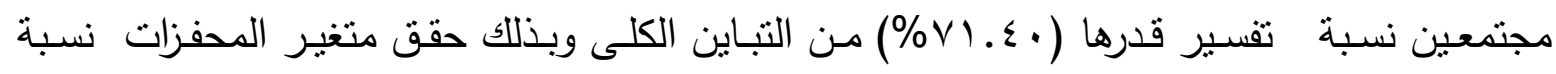
مساهمة قدرها ( .19.1 \% مكا توضح الحالة او الخطو الثالثة للمتغيرات الثلاثة وهم المعلومات و المحفزات و وحدة اتخاذ القرار مجتمعين نسبة تفسير قدرها (0.0^\%) من التباين الكلى وبذللك

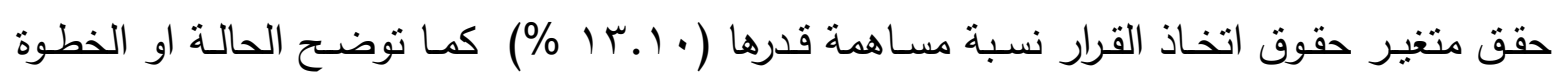

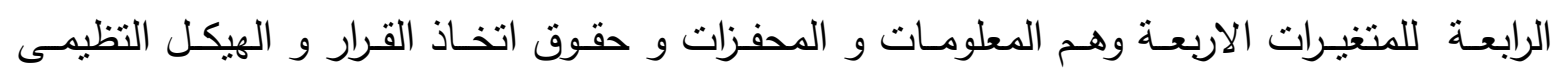

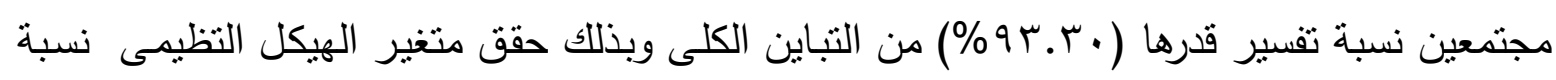
مساهمة قدرها (.A.^ \% ملى المتغير التابع كما يوضح الجدول نتائج تحليل تباين الانحدار المتعدد

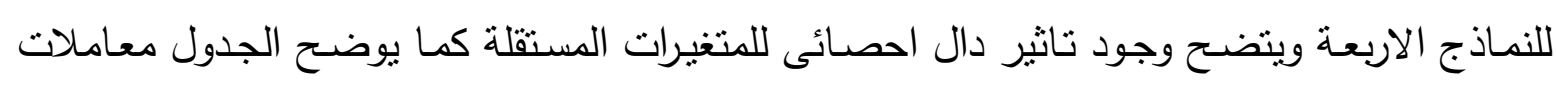

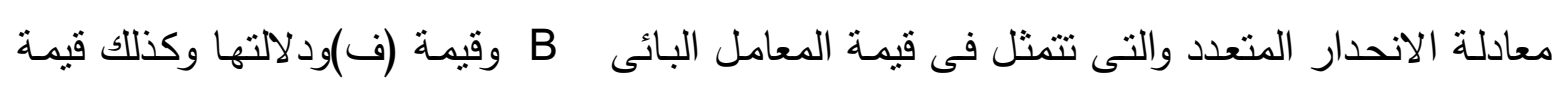
المقدار الثابت ويمكن صياغة معادلات الانحدار المتعدد التى تعين على التتبؤ بدرجة المتغير التابع بمعلومية درجات المتغيرات المستقلة بالصورة التالية

$$
\begin{aligned}
& \text { y المتغير التابع = y } \\
& \text { A المقدار الثابت } \\
& \text { B=معامل الانحدار } \\
& \text { X } \\
& \mathrm{Y}=\mathrm{a}+\mathrm{B} 1 \times 1+\mathrm{B} 2 \times 2+\mathrm{B} 3 \times 3+\mathrm{B} 4 \times 4
\end{aligned}
$$

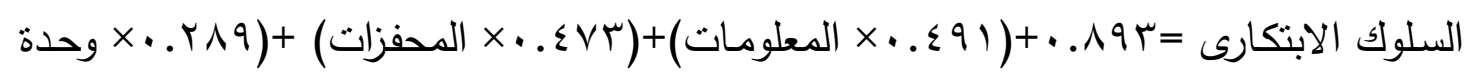

+اتخاذ القرار )

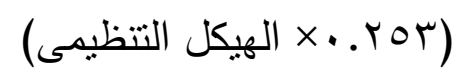




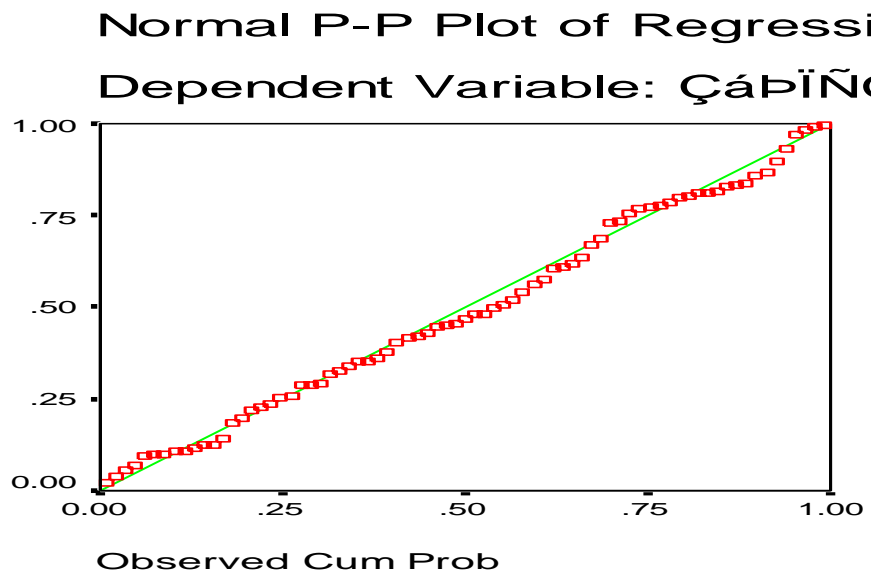

يلاحظ من الثكل السـابق أن معظم النقاط تقع على الخط المستقيم او بالقرب منة مما يدل على التوزيع الاعتدالى للبواقى المعيارية وذلك لانحدار الجينات التتظيمية قيد البحث على منغير السلوك الابتكارى

\section{Scatterplot}

Dependent Variable: ÇápïÑÇÊ

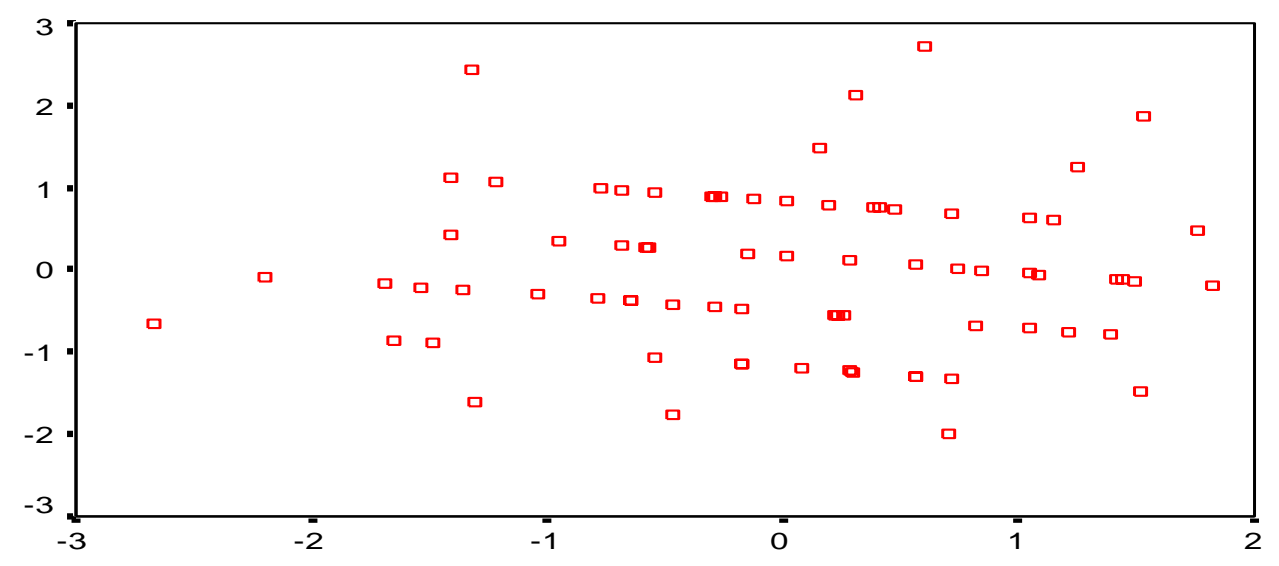

Regression Standardized Predicted Value

يلاحظ من الثكل السابق أن انتشار النقاط تتوزع بشكل افقى متساوى حول الصفر وان

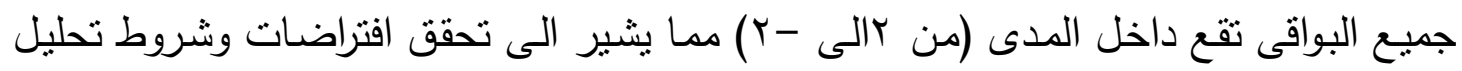

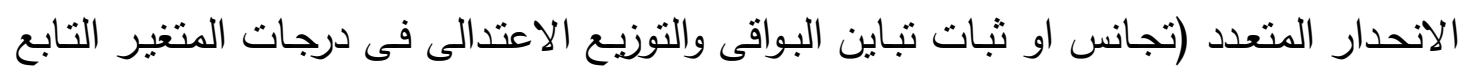

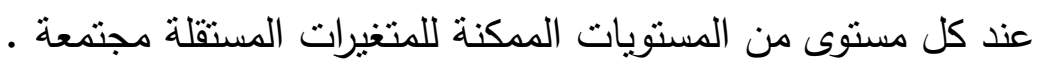
الاستخلاصات والتوصيات: أولا: الإستخلاصات 


\section{من عرض ومناقشة النتائج استخلص الآتي:}

1-وجود تأثنير معنوي لاتخاذ القرار علي القرات الابتكارية للعاملين بالهيئات الرياضية .

r- وجود تأثير معنوي للمحفزات علي القدرات الابتكارية للعاملين بالهيئات الرياضية .

r- وجود تأثثر معنوي لجودة المعلومات علي القدرات الابتكارية للعاملين بالهيئات الرياضية

ع- وجود نأثير معنوي للهيكل التتظيمي علي القدرات الابتكارية للعاملين بالهيئات الرياضية .

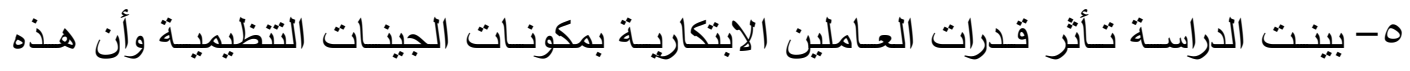

المكونات قد يختلف نرتيب تأثيرها علي قدرات العاملين الابتكارية .

1- ثقافة المؤسسة الرياضية هي اكثر المتغرات التي تعكس حقوق إتخاذ القرار من حيث

النأثير علي قدرات العاملين الابتكارية .

V- القدرة علي التحليل والربط بين الموضوعات المرتبطة بالعمل من أكثر ما يوضح القدرات

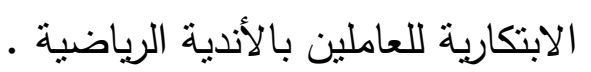

^- السماح للزملاء بالمشاركة في وضع خطط وأهداف العمل بالمؤسسة الرياضية هي أقل الرين المتغيرات التي تعكس حقوق إنخاذ القرار من حيث التأثير علي قدرات العاملين الابتكارية

9- توافر المعلومات يساعد بشكل كبيرعلي تتفيذ مهام العمل بفاعلية .

• 1- توافر المعلومات الوظيفية يدفع العاملين لبذل مزيدا من الجهح لتحقيق أهداف النادي . 11- الهيكل التتظيمـي الجيد يحدد السـلطات والمسئوليات بصـورة واضـحة داخل الانديـة

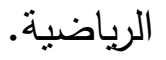

r ا- الاندية الرياضية تحتاج الي توفير التوصيف الوظيفي للوظائف بشكل واضح مما يساعد علي أختيار الوظيفة المناسبة للفرد داخل النادي .

ثانيا : التوصيات

1-يوصي الباحث المسئولين بالمؤسسات الرياضية عامة والاندية الرياضية خاصة الاهتمام بعناصر الجينات التنظيمية الاربعة لما لها من تأثثر علي القرات الابتكارية للعاملين بها r- الاهتمام بطرق تحفيز العاملين سواء المادية أو المعنوية وكذا الالتحاق بالبرامج التدريبية المهنية الني تزيد من قدرتهم علي حل المشكلات والازمات الطارئة . r- إناحة الفرص لمشاركة المرؤسين في صنع وإتخاذ القرارات مما ينمي قدراتهم الابتكارية في مواجهة مشكلات وأزمات العمل . 
ـ - تدعيم الثعور بالرضـا والامـان الوظيفي والعمل علي تحسين الرواتب والمكافأت بشكل

$$
\text { دوري مما يزيد من قدرات المرؤسين الابتكارية . }
$$

0- ضرورة وجود نظام متكامل للمعلومات بالنادى ذات جودة وتوقيت جيد عند الحاجة إليها

$$
\text { بساهم بشكل كبيرفي زيادة قدرات المرؤسين الابتكارية. }
$$

7- السعي الي توافر المعلومـات الوظيفية بسـاعد العاملين علي الابتكار ممـا يساهم في

تحقيق أهداف النادى.

المراجع

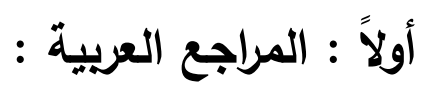

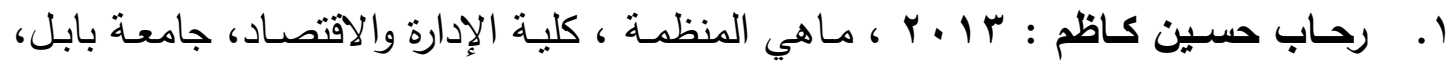

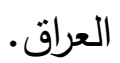

r. سالم سليمان الصابر ، فاضل عباس العامرى ، صباح حميد على : 1 . . ب ، الابتكار

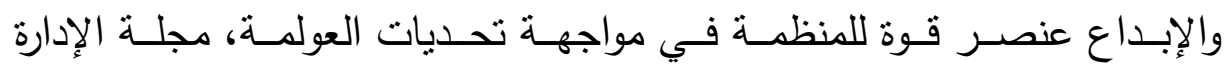
والاقتصاد ، العدد الثاني والسبعون. r. شاهيستا السعيد لبده : 10 ـ ب، أثز الجينات التنظيمية على قدرات المرؤوسين الابتكارية، رسالة دكتوراه في إدارة الأعمال، كلية التجارة، جامعة طنطا.

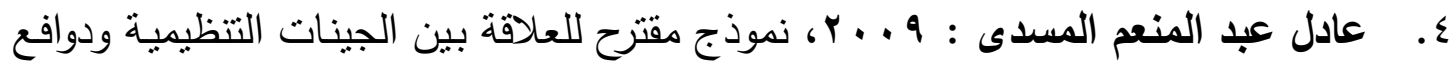

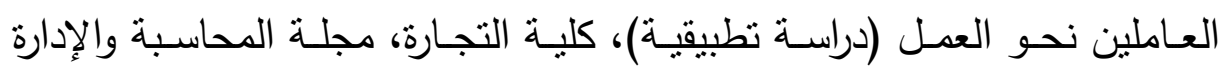
والتأمين، العدد الثاني والسبعون، جامعة القاهرة.

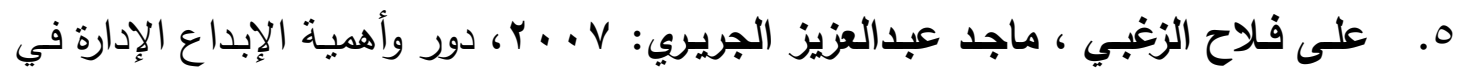

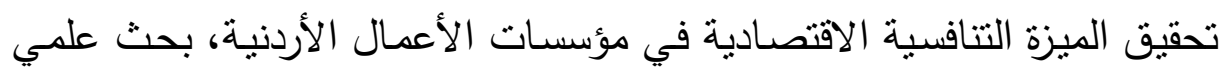

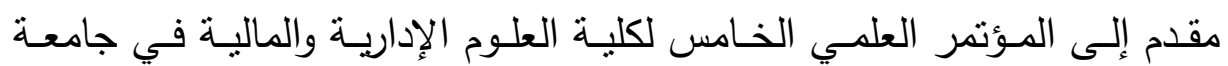
فيلادلفيا.

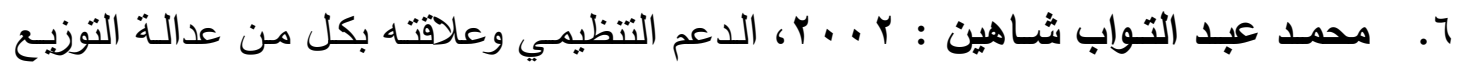
والمشـاركة في اتخـاذ القـرارات والكفـاءة الاجتماعيـة، مجلـة البحـوث الإداريـة، أكاديمية السادات للعلوم الإدارية، محلق العدد الأول.

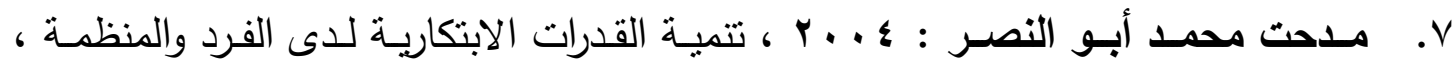
مجموعة النيل العربية ، القاهرة . ثانيًا : المراجع الأجنبية :

8. Agrawal, Reena : 2006, "Innovation: A DNA of organization 
Success", Conference on Global Competition \& Competitiveness of Indian corporate.

9. Ahmed Qammar; Muhammad Zeb Khan, Muhammad Siddique : 2007, "Impact of demographics on organizational support and employees motivation", Journal of managerial science, volume 1,Number2.

10. Andrea Vaona, Mario Pianta : 2008, "Firm Size and innovation in European Manufacturing", Volume 30, Issue 3, pp 283-299.

11. Bordia, Rakesh, Eric Kronenberg and David Neely : 2005, Innovation's Org DNA, Booz Allen Hamilton.

12. Clay Dibrell; Peter S. Davis \& Justin B. Craig : 2008, Fueling Innovation through Information Technology in SMEs, Journal Article, Bond University's Repository Coordinator.

13. DeAnne Aguirre, Lloyd W. Howell Jr., David Kletter, and Gary L. Neilson: 2005, A Global Checkup: Diagnosing the Health of Today's Organizations, global check up, orghealthnov, pdf.

14. Edwin Booz, Allen Hamilton: 2002, When Everyone Agrees, But Nothing Changes: Aligning People, Incentives and knowledge to overcome organizational inertia", Business strategy Review, available at: https://studylib.net/doc/18190262/when-everyone-agrees-but-nothing-changes

15. Gary L. Neilson, Bruce A. Pasternack, and Decio Mendes: 2003, The Four Factor of organizational DNA, Issue 33, Originally Published by Booz \& Company, Available at : https://www.strategy-business.com/article/03406?gko=4f638

16. Gera Surendera, Gu Wulong : 2004, effect of organizational innovation and information technology on firm performance, The International Productivity Monitor, No. 9., Industry Canada nor Statistics, Canda.

17. Izzet Döş: 2007, School DNA and Its Transfer, American Journal of Human Ecology, Vol.2, No1, P. 7-15, University of Stuurman, Kaframanmaras, Turkey.

18. John F. Barnes: 2008, "High performance organizations: Programming Organizational DNA for Success", Southwest Foundation for Biomedical Research., R., Morrone, D.A. 
19. Leo F.C. Bruno: 2010, "The impact of organizational culture on innovation management", E-Leader Conference Budapest, Brazil.

20. MichaelWest;Carol S. Borrill; Jeremy F. Dawson; FelixBrodbeck; David AShapiro; BobHaward: 2003, Leadership clarity and team innovation in health care. In: The Leadership Quarterly, Vol. 14, No. 4-5, 08.2003, p. 393-410.

21. Rob Nielsen, Jennifer A. Marrone, Holly S. Slay: 2010, A New Look at Humility: Exploring the Humility Concept and Its Role in Socialized Charismatic Leadership, Journal of Leadership \& Organizational Studies, available at: https://doi.org/10.1177/1548051809350892

22. Steve Scheier: 2012, "Putting the Right people Behind the wheel; How Decision Clerity Driver Innovation, Supports Social Responsibility and Optimize Long term Value" , http://www.mamagementexchemge.com/hack/puttingrightpeople-behindwheel.

23. Tim Kastelle: 2012, The Innovation Matrix Reloaded, Again, University of Queensland Business School, Available at: http://timkastelle.org/blog/2012/04/the-innovation-matrixreloaded-again/

24. Vladimir Perović and Gordana Komazec: 2007, Creativity as a factor in competitiveness on the international market, Journal for Labour and Social Affairs in Eastern Europe, Vol. 10, No. 3, 'Economic, political and demographic change', pp. 5771

25. Yu Zhou; Yingying Zhang \&Ángeles Montoro- Sánchez: 2011, Utilitarianism or romanticism: the effect of rewards on employees' innovative behavior, International Journal of manpower, 32 (1), 81-94.

$$
\text { ثالثًا : مواقع شبكة المعلومات الدولية : }
$$

26. http://elsharg.tv/node/53245.

27. http://www.aoulef.com/t1110-topic. 